\title{
Más poemas sefardíes de contenido histórico*
}

Como complemento a su libro Entre dos (o más fuegos), donde se publicaban textos poéticos sobre diferentes acontecimientos de la historia de los sefardíes del Imperio otomano y de los Balcanes, en el presente artículo la autora edita y estudia otros 20 poemas ( 8 de ellos coplas) de interés histórico, escritos por autores como Alexandro Pérez̧, Ya 'acob Mošé Altaráŝ, Sa 'adi Haleví, Eliyá Carmona, etc., y que abordan variados temas, algunos ya tratados en Entre dos y otros nuevos, entre los que cabe resaltar: el bombardeo de Belgrado de 1862; la ocupación de Bosnia por los austriacos en 1878; el incendio de Sarajevo de 1879; la comunidad sefardí de Constantinopla en 1922; Inglaterra y la Palestina de 1939; el Holocausto; la independencia de Israel y la dura vida en 1949 y en 1952 en el flamante estado; la guerra fría y la de Corea de 1952; etcétera.

Palabras clave: Historia de los sefardíes de los Balcanes; poesía sefardí; coplas sefardíes; poetas sefardíes; el Holocausto; el Estado de Israel; edición de textos judeoespañoles; léxico judeoespañol.

More Sephardic Poems of Historical Content. - In addition to her book Entre dos (o más fuegos), where the author published poetical texts concerning different events in the history of the Sephardic Jews in the Ottoman Empire and the Balkans, she offers here the edition and study of more than 20 historical poems (among them, 8 "Coplas"), written by authors such as Alexandro Perez̧, Ya'acob Mošeh Altaraŝ, Sa 'adi Halevi, Eliyah Carmona, etc. The texts deal with a range of variegated issues, some already previously studied, and some new, among them, the bombardment of Belgrade in 1862; the Habsburg occupation of Bosnia in 1878; the fire of Sarajevo in 1879; the Sephardic community in Constantinople in 1922; Great Britain and Palestine in 1939; the Holocaust; the independence of Israel and the tough life in the new State in 1949 and in 1952; the Cold War and the Korean War in 1952; etc.

KeYwords: History of the Sephardic Jews in the Balkans; Sephardic Poetry; Sephardic "Coplas;" Sephardic Poets; Holocaust; State of Israel; Edition of Judeo-Spanish Texts; Judeo-Spanish Glossar.

* El presente artículo se ha elaborado en el marco del proyecto de investigación del Plan Nacional I+D+I: «Sefarad siglo XXI (2009-2011): Edición y Estudio Filológico de Textos Sefardíes» (SGPI, MICINN, FF2009-10672 [subprograma FILO]).

**elena.romero@cchs.csic.es 


\section{Generalidades}

Ya en la Introducción de mi libro Entre dos (o más) fuegos ${ }^{1}$ hacía la siguiente salvedad:

Antes de pasar adelante conviene precisar algo: que con este libro no queda agotado el tema, ya que soy consciente del mucho material poéticohistórico que aún debe quedar por descubrir en impresos y manuscritos, y muy principalmente en la prensa periódica judeoespañola, cuyo despojo sistemático del material que ahora nos ocupa no he llevado a cabo.

Creo llegado el momento de publicar yo misma otro lotecillo de textos -20 en total: numerados 19, más un texto en dos versiones (núms. 7A-7B)- que responden a esa misma categoría de poemas y coplas de contenido histórico.

Los temas son muy variados. En algunos casos se trata de asuntos de los que ya me ocupaba en Entre dos y de los que ahora puedo añadir nuevos textos que los abordan o nuevas versiones allí no tenidas en cuenta; así, por ejemplo, núms. 1 (Ruşdí Pachá), 2 (Bejor Carmona), 6 (cumpleaños de Abdul Hamid), 9 (crisis económica), 11 y 13 (críticas a los ricos) y 12 y 18 (historia social). En otras ocasiones los textos se ocupan de temas que de intento dejé fuera en Entre dos y que, por los motivos que indico en sus respectivas entradillas, he decidido abordar ahora, a saber: el Holocausto (núm. 14), el Estado de Israel (núms. 15-17) y el mundo tras la Segunda guerra mundial (núm. 19), traspasando en este caso el límite cronológico que me impuse en Entre dos. Y finalmente, un lote de 6 textos (núms. 3-5, 7-8 y 10) nos cuentan hechos «novedosos» no tratados en Entre dos, $\mathrm{y}$, de haberlos encontrado antes, tendrían que haber aparecido en mi citado libro, pero..., nunca es tarde si la dicha es buena, que decían nuestros mayores.

Por lo que respecta a lo formal, son coplas 8 textos: los núms. 2, 8, 10, 15 y 19, nonetas octo-hexasílabas; los núms. 11 y 13, cuartetas de rima a la zejelesca; y el 7, sextillas de pié quebrado. Los restantes 11 (núms. 1, 3-6, 9, 12, 14 y 1618) son poemas de diferentes esquemas estróficos.

En cuanto a los autores, 6 textos me han llegado anónimos (núms. 2 y 9-13); otros 6 los escribió Alexandro Pérez̧ (núms. 14-19); 4 son de Ya'acob Mošé Altaráŝ (núms. 1 y 3-5); y con un poema están representados Sa ‘adi Haleví (núm. 7) -texto que me ha permitido descubrir otro plagio de Ya'acob Yoná-, Eliyá Carmona (núm. 8) y el poeta que firma con el seudónimo «Habacuc» (núm. 6).

\footnotetext{
${ }^{1}$ Elena Romero, Entre dos (o más) fuegos: Fuentes poéticas para la historia de los sefardíes de los Balcanes (Madrid 2008) págs. 21-22.
} 
Salvo dos textos que proceden de fuente manuscrita (núms. 2 y 7B), la mayoría me han llegado impresos: 11 en libros, tanto aljamiados (núms. 1, 3-5, 7A y 14-16), como en letras latinas (núms. 17-19); y 7 vieron la luz en periódicos aljamiados de Salónica (núms. 6 y 9-13) y de Constantinopla (núm. 8).

En mi edición sigo los mismo criterios de presentación que en Entre dos y la ordenación es también la cronológica. En Glosario final se recogen las palabras de difícil comprensión.

\section{Edición DE LOS TEXTOS}

\section{Rusdí Pachá y los judíos de Sarajevo}

El texto que publico procede de la siguiente fuente única:

- Versión aljamiada publicada en el libro de Ya'acob Mošé H. Altaráŝ, Séfer Źijrón Yerušaláyim «[...] y las hablas traídas de más, como ma'asiyot, ecǰemplos y haruźim son porque pasen el tiempo y tomar de ellos musar [...]» (Belogrado 1887) págs. 220-2212.- Cabecera: «El ma'asé de los priśioneros $^{3}$ que aconteció en civdad de mi nacimiento Saray, y'E”a».

Poema de Ya'acob Mošé H. Altaráŝ, compuesto por lo que parecen ser 23 estrofas de cuatro versos monorrimos sin medida, con una cierta tendencia a ser octosílabos, si bien también podría considerarse prosa rimada, en la que por otra parte abunda Altaráŝ en su obra. El texto aparece escrito en línea seguida sin ninguna partición.

El poema nos habla de la salvación de los dirigentes y rabino de la comunidad sefardí de Sarajevo a quienes había mandado ejecutar el valí Rüşdí Pacha el 23 de octubre de 1819. De tal asunto ya me he ocupado ampliamente en mi libro Entre dos (cap. 5, aprt. C págs. 183-198), donde edito el poema (núm. 22) que titulo Los abusos de Rusdí Pachá (págs. 185-191) y la copla (núm. 23) de Los milagros de rabí Danón (págs. 191-198), y donde también recojo relatos en prosa del suceso en los Apéndices II (págs. 813-825) y III (págs. 827-837).

Esto es lo que nos cuenta el «nuevo» poema. El autor lo escribe para rememorar aquel milagro y que las gentes tengan memoria de lo sucedido (estrs. 1-2). Mucho sufrieron los judíos de Sarajevo, a cuyo gobernador, Rüşdí Pachá habían hablado mal de los judíos (estrs. 3-4), por culpa de un judío renegado y convertido al islam que había muerto por sus pecados. Decide el malvado

\footnotetext{
${ }^{2}$ Uso fotocopia del ejemplar de la Jewish National Library (JNL) S 34V90.

${ }^{3}$ Sobre este título vid. mi comentario infra.
} 
Rüşdí castigar a los dirigentes de la comunidad (estr. 5), si no pagan una fuerte cantidad de dinero como rescate, lo que resulta imposible debido a la pobreza de los judíos locales (estr. 6). Ordena Rüşdí la prisión de nueve dirigentes junto con el rabino y los condena a muerte (estrs. 7-8). Los judíos lloran y se sumen en plegarias a Dios, $y$, al recibir durante la oración del sábado la noticia de que los presos van a ser ejecutados ese mismo día (estrs. 9-10), buscan la ayuda de los turcos locales (estr. 11), lo que consigue un buen judío, el cual entra en un cafetín turco, invita a los presentes, cuenta los sucedido y compra la voluntad de uno de los parroquianos, quien reúne en su apoyo a algunos otros turcos (estrs. 13-14). El buen turco, de nombre Asán, regresa a su casa, toma armas y caballo e incita a la revuelta por las calles, a lo que contribuyen los judíos, repartiendo dinero para animar a sus benefactores (estrs. 15-17). Llegados al lugar donde están encerrados los apresados, rompen cerrojos y puertas, liberándolos (estr. 18). Tras ello los revoltosos se dirigen al palacio del gobernador con idea de matarlo; pero avisado Rüşdí por sus criados, consigue librarse huyendo por la ventana y escapando descalzo de la ciudad (estrs. 19-20). El autor precisa que todo aquello sucedió hace 80 años, un sábado 4 de ḥešván (estr. 21), y que hasta el día de hoy se sigue festejando aquel acontecimiento para dar gracias a Dios, que los salvó, y a los turcos, que los ayudaron (estr. 22). El poema se remata con las tópicas frases de esperanzas en la pronta llegada del mesías (estr. 23).

Resulta interesante comparar los motivos que recoge el texto con las otras fuentes conocidas en prosa y en verso. Resumo lo que en Entre dos (págs. 183185) decía al respecto de tales sucesos, lo que de paso aclara algunas alusiones de nuestro poema.

En tiempos de Mahmud II y siendo gobernador de Bosnia Mehmed Pachá, un judío de nombre Mošé Havillo, de Travnik, convertido al islam con el nombre de Ahmed y miembro de la orden de los derviches, decidió vengarse de sus antiguos correligionarios, instando al gobernador a oprimir a los judíos con fuertes impuestos; pero el gobernador, no sólo no escuchó sus palabras, sino que lo sometió a juicio, y, encontrándolo culpable, lo condenó a muerte. Ese es el pecado al que se alude en estr. 5.

Los derviches locales culparon de su muerte a los judíos y con la llegada a Bosnia en 1819 del nuevo gobernador, Mehmed Rüşdí Pachá, acudieron a visitarlo a su residencia en Travnik para acusar a los judíos de la muerte de Ahmed; estos son los que hablaron mal de lo judíos según la estr. 4. En su primera visita a Sarajevo Rüşdí hizo apresar al rabino Mošé Danón -cuyo nombre no figura en nuestro texto- y a los notables de la comunidad cuyo nú- 
mero varía en las fuentes -diez, doce o siete ${ }^{4}$; en estr. 8 se habla de nueve, sin que quede claro si el rabino está incluido o no en el cómputo-, exigiendo por su rescate la elevada suma de 500 bolsas de ducados de oro, cantidad que en nuestro texto no se precisa y que los judíos locales debían pagar en el plazo de tres días, es decir, el sábado siguiente: 4 del mes de ḥešván (= 23 oct. 1819), como se recuerda en estr. 21.

Un sefardí llamado Refael Haleví (o Leví) -el innominado «j̣udío abonanzado» de estr. 12- y respetado por sus conciudadanos bosnios, consiguió que éstos tomaran la causa de los judíos como propia. El sábado en el que vencía el plazo, 3.000 hombres armados hasta los dientes y al mando de un guerrero local de nombre Ahmed Bayraktar Verlevski -que inopinadamente en un texto como el nuestro, tan parco en mencionar los nombres de los personajes de la historia, aparece denominado Asán (estr. 15)-, atacaron de improviso la residencia del gobernador, liberando a los judíos y apresando a Rüşdí Pachá; éste, al parecer, consiguió regresar a Travnik. Pero siendo requerido por el sultán, al final fue ajusticiado.

También, como leemos en estr. 22, para conmemorar su salvación milagrosa, los judíos de Sarajevo decidieron festejar anualmente el 4 de ḥešván, día al que denominaron -tal y como dice la cabecera de nuestro texto- Hag haasirim (hb. 'Fiesta de los prisioneros') ', lo que estuvieron haciendo durante más de medio siglo.

Resulta interesante la mención en nuestro texto de la entrada en el cafetín de Refael Haleví, de su invitación a una taza de café a todos los presentes y de su entrega de un ducado a modo de soborno (estrs. 12-14), soborno reforzado en este poema -y motivo que no conozco por otras fuentes- por los dineros que los judíos reparten por las calles a los seguidores del improvisado liberador turco (estr. 17). Repito aquí, resumiéndolo, lo que al respecto recogía en Entre dos (Ap. II págs. 819-825), según el relato en prosa titulado Meguilá de Sarajevo, de Isak Samokovljia.

$\mathrm{Al}$ acabar la cena [del sábado] y cuando aún ardían las velas sobre la mesa, [Refael Haleví] se levantó [...], cogió una bolsa de ducados y, poniéndolas en su bolsillo, salió, dirigiéndose a las callejuelas del barrio.

Aquellas calles eran ocho y en cada una había un cafetín en los que entraban sólo musulmanes, pues los demás tenían prohibido el acceso y sentarse en ellos. Y llegó el gran justo a un cafetín y, entrando en él, se

\footnotetext{
${ }^{4}$ Sobre el diferente número de los apresados vid. Entre dos pág. 187.

${ }^{5}$ Sobre este título vid. Entre dos Ap. II pág. 813.
} 
sentó junto a la puerta [...] [Tras tomarse un café ...] y, como era costumbre al pagar esos cafés dejar sobre el mostrador una moneda para los pobres, también lo hizo Refael Haleví, pero, en lugar de un céntimo, dejó sobre el mostrador un ducado.

En cuanto a por dónde huyó el valí, la ventana salvadora de estr. 20 parece ser un invento de nuestro poema. En el relato de Isak Samokovljia el valí no logra huir, siendo apresado por los sublevados. Pero la mención de otra escapatoria la encontramos en el librito en judeoespañol Los sefaradim de Bosna, «por D"r Moris Levi, gran raḅino de Sarayevo; adaptado del almán» (Salónica 1932) (págs. 26-27), donde se dice (Entre dos págs. 814-815) que «El pačhá pudo fuyir de su caśa por una puerta de atrás».

Cabe preguntarse por la fuente de inspiración de Altaráŝ para la elaboración de su poema. A pesar de la coincidencia con la cabecera de nuestro texto $-\ll \mathrm{El}$ ma 'asé de los priśioneros»- no pudo ser el relato La historia de los prisioneros que hacia 1895, es decir, unos diez años después de la publicación de nuestro texto (1887), escribiera Mošé Refael Attías (Zeki Efendi), obrita en judeoespañol cuyo original parece no haberse conservado. Como ya he mencionado, también se denominaba 'Fiesta de los prisioneros' (Hag haasirim) la de conmemoración de los acontecimientos.

La coincidencia del título con el que parece haber sido la denominación tradicional del suceso, así como la mención de motivos reiterados en unos y en otros textos en prosa y en verso, me hace pensar en la existencia de un magma de transmisión oral del que cada autor se ha servido a placer.

Veamos ya el texto.

1 Me asentí sobre rodías por escribir ditas maravías, porque sientan muestras famías los milagros con alegrías

2 y que tengan sienpre membración por muestros padres y sus escapación que tuvieron en esta ocasión con haćer a el Dio oración.

3 Saray, civdad la afamada, años antigos fue angustiada, de achaques y males hartada, de yišme 'elim ella ${ }^{6}$ sobre-forzada.

\footnotetext{
${ }^{6}$ Dice ellas.
} 
4 Los jidiós muncho llevaron en tienpo de Rus̀dí Pačhá y su ĝente cuando podestaron: a este pačhá mal le hablaron por los jidiós que en Saray se toparon.

5 Por cavśa de un jiidió ỵoltado que por su pecado fue matado, del Pačhá Rus̀dí fue juźgado que el kolel de los jidiós seya castigado.

6 Suma grande fue taxada, de los ĵidiós que seya tomada $\mathrm{y}$, siendo eran ĝente aprobada ${ }^{8}$, la suma de moneda non pudo ser ajuntada.

7 Estonces fue setenciado del pačhá nombrado por que seya cada memuné enpreśado junto el s"e rab estimado.

8 Mueve memunim fueron cerados, junto el s"e rab juźgados; en cerca tienpo fueron condenados que a tajo de espada tienen de ser matados.

9 Esto se fue sintiendo, los ĵidiós por toda la civdad ruyendo, alguaya ${ }^{9} \mathrm{y}^{10}$ endecha engrandeciendo ${ }^{11}$ y oraciones a el Dio iban haćiendo.

10 Un día de šaḅat estando los jidiós en el c"c séfer Torá meldando, vinieron ĝente gritando que este día a los apreśados van ir matando.

11 Todos la oración dejaron, por las calles se andaron

\footnotetext{
${ }^{7}$ Es decir, fue sentenciado por el pachá.

${ }^{8}$ Es decir, pobre.

${ }^{9}$ Escrito אלגרייאה.

${ }^{10}$ Repetido $y$.

${ }^{11}$ Es decir, con gritos y lamentos cada vez más fuertes.
} 
ayudas y mamparos bušcando ${ }^{12}$

y con algunos amigos turcos se conyuraron.

12 Un ĵidió abononanzado

se fue a la cavané haćer su estado ${ }^{13}$,

antes que fuera asentado

por su dicho un cavé a cada turco fue conỵidado.

13 Sus amigos turcos le demandaron

de qué sus ojos aguas de lloro aḅajaron;

les habló lo que condenaron

sobre los jidiós que enceraron.

14 A uno de ellos, abonanzado, le encajó en su mano un ducado, de vista él fue alevantado

y apañó más de su ĝente a su lado.

15 Este turco fue nombrado

Asán, el abonanzado,

a su caśa se anduvo ensañado

y sobre su caballo fue cuatriguado ${ }^{14}$.

16 Con prisa fue armado

él y su caballo enborachado ${ }^{15}$,

gritando: «Quen es turco que seya armado ${ }^{16}$

en ayuda de cada jidió enpreśado».

17 Iba apañando gente y gritando,

«Escapemos a muestros civdadinos» dićiendo,

detrás de él se iban acoǵendo

y los ĵidiós oración haćiendo y šóḥad esparćiendo.

18 Se alevantaron y vinieron

onde los enpreśados estuvieron,

los senĝeres y puertas ronpieron

y a los encerados jidiós riḥmieron.

\footnotetext{
${ }^{12}$ Habríamos esperado bušcaron que no estropearía la rima.

${ }^{13}$ Entiendo que quiere decir a sentarse allí, pero también cabe entender a hacer lo que tenía por costumbre.

${ }^{14}$ Es decir, se subió en su caballo.

${ }^{15}$ No sé si de vino o de cólera.

${ }^{16}$ Es decir, que se arme.
} 
19 De este lugar se anduvieron, por matar a Rus̀dí Pačhá corieron; sus servidores al pačhá se lo dijeron que turcos a matarlo vinieron.

20 El pačhá fue por su ventana echado y asimiśmo escapado; fuyó de la civdad descalzado y del estado fue rematado ${ }^{17}$.

21 Este día de šabat santificado fue cada enpreśado escapado; día de 4 ḥešván estimado, hoy de esto cerca de 80 años ajustados.

22 'Od hayom fiesta lo haćemos este día cuando tenemos ${ }^{18}$; tanbién al turco bendećiremos que fue šalíah del Dio que lo nombremos.

23 Non mośotros aḅasteceremos por alabar a el Dio que creemos ${ }^{19}$ nos y el semen que ternemos hasta días del untado que queremos.

\section{Bejor Carmona, Yeḥeźquel Gabay y el armenio Duz Oglú}

El texto que publico procede de la siguiente fuente:

- Versión aljamiada en el manuscrito Limŝó imré šéfer (Bucarest ca. 1825) fol. $36 b^{20}$.- Cabecera: «Complas del guebir».

Copla anónima de solo dos nonetas octo-hexasílabas, que se corresponden con las dos primeras del texto que edito en mi libro Entre dos (cap. 5 núm. 26 págs. 210-220: ed. págs. 214-220) a partir de la versión de 22 estrofas del Ms. Teśa (Oriente 1820 o 1825). Indico entre corchetes las lecturas

${ }^{17}$ No sé si fue rematado se refiere a que lo echaron de su cargo (estado) de valí o si el estado es aquí la Sublime Puerta que lo mandó ejecutar.

${ }^{18}$ Quizá quiera decir cuando tenemos ocasión de celebrarlo, cuando podemos hacerlo; pero también cabe entender: cuando llega dicho día.

${ }^{19}$ Es decir, en el que creemos.

${ }^{20}$ Uso fotocopia del ejemplar del Jewish Theological Seminary of America (JTSA) Acc. 02516 . 
variantes de dicho manuscrito con la presente versión. Sobre su contenido véanse mis comentarios en Entre dos (loc. cit.).

1 Oíd [Oyid] complas [coplas] del guebir, que no veamos faltura, que siempre [sienpre] por el probe él muncho procura [percura]; el Dio [no Dio] de la altura que vaya con él, [que] lo envió a llamar el rey; ipor bien que le seya [sea], enaltezca la su estrella [estrea]! ¡Ya! [nunca Ya].

2 «Buen šapchí tú eres, que bueno te enmentas [mentas]; la lecencia ya te di a quen [lo que] queres que metas. En mi lugar te entremetas: esto es mi demanda.

El Dio es de [esté por] tu vanda, de [con] ti y de [no de] tu hermano que estéš [estés] ỵivos [ỵivo] y sanos [sano]. ¡Ya!

\section{El bombardeo de Belgrado de 1862}

El texto que publico procede de la siguiente fuente única:

- Versión aljamiada publicada en el citado libro de Ya'acob Mošé Ḥ. Altaráŝ, Séfer Źijrón Yerušaláyim (Belogrado 1887) págs. 223-224 ${ }^{21}$.

Poema de Ya'acob Mošé Ḥ. Altaráŝ, compuesto por lo que parecen ser 6 estrofas de cuatro versos monorrimos, siendo mayoritarios los de ocho y nueve sílabas, si bien, como en el caso del texto núm. 1, también podría considerarse prosa rimada. Está escrito en línea seguida sin ninguna partición. Figura tras el texto relativo al incendio de Sarajevo (núm. 5 infra) y separado de él por la indicación «Tam Tam» con el que aquel finaliza; mi cambio de orden se debe a respetar la ordenación cronológica de los acontecimientos.

El poema nos habla de un acontecimiento no recogido en mi libro Entre dos, siendo, pues, una nueva aportación al esclarecimiento de la historia de los sefardíes de los Balcanes. Veamos en primer lugar su contenido y después aclararé la situación histórica.

Hace años los habitantes de Belgrado escaparon de un grave problema gracias a la ayuda divina (estrs. 1-2). El 17 de junio de 1862 los judíos de la ciudad se salvaron de un terrible bombardeo, en el que, según le han contado al autor,

${ }^{21}$ Vid. nota 2 supra. 
los cañonazos sobrevolaban la ciudad (estrs. 3-4); a veces las bombas caían en las casas judías sin que hubiera que lamentar víctimas (estr. 5), milagro por el que deben dar gracias a Dios (estr. 6).

Para aclarar la situación histórica resumo datos que ya exponía en Entre dos (cap. 5 págs. 175-176, y cap. 6 págs. 246-248).

Los serbios, en armas desde el reinado de Selim III, fueron sometidos por Mahmud II entre 1813 y 1814, llevándose a cabo terribles represalias. Tales atrocidades provocaron en 1815 una nueva sublevación, que cogiendo a los turcos por sorpresa, los llevó a la derrota; el sultán prefirió tratar con los insurrectos, concediendo al jefe del movimiento, Miloš Obrenović, el título de jefe supremo de los serbios y una parte del poder del pachá: la administración, la justicia y la percepción de impuestos.

Con el paso del tiempo Obrenović, gracias a una política paciente y astuta, consiguió obtener una completa autonomía, recibiendo el título de príncipe hereditario de los serbios; los privilegios del nuevo principado se fueron precisando en los años siguientes y se ratificaron el 30 de marzo de 1856 en el Tratado de París, que puso fin a la guerra de Crimea, donde se reconocía la autonomía de Serbia, si bien respetando la soberanía de Turquía, que continuaba percibiendo un tributo y manteniendo guarniciones en ciertas plazas fuertes, entre ellas Belgrado. Miguel Obrenović, que había sucedido a su padre en 1859, ardía en deseos de independizarse de los turcos, y según nos dice, por ejemplo, René Ristelhueber ${ }^{22}$ un hecho banal vino a permitirle ver realizado su deseo de verse libre de las guarniciones turcas; reproduzco sus palabras:

La presencia de soldados turcos daba lugar a menudo, sobre todo en Belgrado, a altercados con la población. En junio de 1862, un niño servio fue muerto durante una contienda y el pueblo se amotinó. Ya parecía todo en calma, cuando desde la ciudadela la guarnición turca empezó a bombardear la capital, lo que continuó haciendo durante varias horas.

Este acto de inútil crueldad promovió una viva conmoción en Europa. Por iniciativa de Francia, se celebró una conferencia en Constantinopla para tratar de la retirada de las guarniciones otomanas. Ante la oposición de Austria y de Inglaterra, hubo que contentarse con la demolición de dos fortalezas. Pero [...] en 1867 [...] fueron retiradas las guarniciones, saliendo del territorio hasta el último soldado turco.

\footnotetext{
${ }^{22}$ En Historia de los pueblos balcánicos (Madrid 1962) pág. 123.
} 
Veamos ya el texto.

1 Tanbién los que fueron topados en Belogrado años pasados ellos fueron escapados de males de todos los lados ${ }^{23}$.

2 Ellos vieron las maravías que les hiźo el Dio demaśías ${ }^{24}$; a todos con sus famías los escapó con alegrías.

3 Año 5622 ajustado ${ }^{25}$, día de 19 siván ${ }^{26}$ estimado, pueblo de la angustia fue escapado, que es día de la bombardimá nombrado.

4 Asegún me fueron contando, los que se fueron ${ }^{27}$ topando que las yulés de tiros iban pasando de la una parte a la otra matando.

5 A las većes cayiban sobre las moradas yulés de tiros encargadas y en caśas de jijidiós aunadas ${ }^{28}$, ma las almas fueron escapadas ${ }^{29}$.

6 A este milagrośo día deben nombrarlo con alegría quen que escapó él y su famía y non lo sudeció ninguna manćía.

${ }^{23}$ Como he mencionado arriba, el también inicial de la estrofa establece la relación con los dos textos que le preceden, los que titulo La ocupación de Bosnia por los austriacos en 1878 y El incendio de Sarajevo de 1879 (núms. 4-5 infra).

${ }^{24}$ Es decir, que Dios les hizo en abundancia, en grandes cantidades, más de lo esperado.

${ }^{25}$ Con ajustado no sé si quiere decir: justamente el día que se indica en verso siguiente.

${ }^{26}$ Equivalente al 17 de junio de 1862.

${ }^{27}$ Que más creo que se trate de huyeron

${ }^{28}$ Es decir, que las casas de los judíos estaban juntas.

${ }^{29}$ Es decir, que no murió nadie. 


\section{La ocupación de Bosnia por los austriacos en 1878}

El texto que publico procede de la siguiente fuente única:

- Versión aljamiada publicada en el citado libro de Ya 'acob Mošé Ḥ. Altaráŝ, Séfer Źijrón Yerušaláyim (Belogrado 1887) págs. 221-223 ${ }^{30}$.- Cabecera: «Ma'asé de cuando entró el nemŝí en la Bosna y en Saray, y“E”a».

Poema de Ya'acob Mošé Ḥ. Altaráŝ, compuesto por lo que parecen ser 19 estrofas de cuatro versos monorrimos de diferente medida, que como decía en textos anteriores procedentes de esta misma obra, quizá deba entenderse como prosa rimada. Está escrito en línea seguida sin ninguna partición, salvo estr. 17 que inicia nuevo párrafo (lo marco dejando un espacio en blanco), y también unido sin separación alguna al texto que sigue sobre el incendio de Sarajevo de 1879 (núm. 5).

Como en el caso del texto anterior, nos refleja ahora también Altaráŝ un acontecimiento histórico no recogido en Entre dos. Veamos en primer lugar el contenido del texto.

Se inicia el poema mencionando los grandes milagros hechos por Dios en aquellos días (estr. 1). En 1878 llegaron a la ciudad de Sarajevo rumores de guerra (estr. 2), lo que hizo que los turcos empezaran sus preparativos bélicos, empezando también a extorsionar a los judíos (estr. 3). Un hombre llamado Aĝ́i Luyú enardecía a los turcos, supongo que a los civiles, para que se sumaran a las tropas (estr. 4), en tanto que prometía a los judíos ricos librarlos de ir a la batalla a cambio de dinero (estr. 5). Al parecer la ciudad se llenó de soldados que organizaban serias trifulcas (estr. 6). Mientras tanto los judíos estaban angustiados por la suma de dinero que se les exigía (estr. 7), pero ante la pregunta que empezaban a formularse muchos turcos sobre porqué los judíos no se integraban, como hacían ellos, en el ejército (estr. 8), y para evitar mayores males optaron por pagar lo que se les pedía (estr. 9). Los austriacos empezaron a acercarse y había bajas en ambos bandos (estr. 10), hasta que en la madrugada del 9 de agosto de ese año se empezaron a oír cañonazos cercanos, al tiempo que la ciudad se llenaba de soldados heridos (estr. 11). El miedo cundió entre las gentes, que buscaron refugio, y mientras los soldados turcos se encerraban en la fortaleza, los austriacos entraron en la ciudad (estr. 12), agravándose los cañonazos entre uno y otro bando que pasaban sobre la cabeza de los vecinos de la ciudad, siendo milagroso que no hubiera víctimas judías (estrs. 13-15). Tras ocho horas de intenso tiroteo, los turcos se rindieron dando fin a la sañuda batalla a la que siguieron un buen número de ejecuciones (estrs. 16-17). Los judíos dieron gracias a Dios por haber salvado sus vidas y sus

${ }^{30}$ Vid. nota 2 supra. 
haciendas (estr. 18). El autor acaba el poema diciendo que, como todos saben, tal es lo que pasó cuando los austriacos ocuparon Bosnia (estr. 19).

Veamos ahora el trasfondo histórico. Según mencionaba en Entre dos (cap. 7, pág. 294), primero en el Tratado de San Stefano, firmado en marzo de 1878 y que ponía fin a la guerra ruso-turca de 1877-1878, y después en el Tratado de Berlín (13 jul. 1878), se reconocía la autonomía de Bosnia-Herzegovina y el derecho de Austria de ocupar y administrar la zona, solo nominalmente bajo la soberanía del Imperio otomano. Si bien la anexión completa a Austria no se produjo hasta 1908 (Entre dos cap. 11 pág. 529), los austriacos no tardaron en adentrarse en Bosnia y a solo poco días de la firma del Tratado de Berlín, el 9 de agosto, ya estaban -según nos dice nuestro texto- llamando a las puertas de Sarajevo. Al respecto comenta Ristelhueber ${ }^{31}$ que Austria ocupó «no sin resistencia, Bosnia-Herzegovina [...]», siendo nuestro texto un ejemplo de tal resistencia.

Veamos lo que nos cuenta.

1 Grandes son las maravías que hiźo el Dio en muestros días; de contar las demaśías non aḅastece noches y días.

2 Año $5638^{32}$ rehenchidos se enpezó a sentir un gran ruido por la civdad Saray esparćido: reyuelta de guera sentido.

3 Los días iban pasando, los turcos se iban aparejando contra del nemŝí, pensando tanbién a los jiidiós ir apretando.

4 Salió un turco nombrado Aĝ́í Luyú ${ }^{33}$, el ensabanado; enpezó a dar coraǵe a cada enturcado ${ }^{34}$ por que salga al pleito con el fonsado.

\footnotetext{
${ }^{31}$ Ristelhueber Historia pág. 225.

${ }^{32}$ Equivalente a 1878.

${ }^{33}$ Escrito אג'י לוייו, personaje al que no he conseguido identificar y, por tanto, no estoy segura de haber trascrito bien el nombre; probablemente sería el jefe militar de la fortaleza turca de Sarajevo.

${ }^{34}$ Es decir, a todos los turcos.
} 
5 A los ĵidiós aunados ${ }^{35}$ les puso dacios peśgados: que den cada rico suma de ducados y de ir a la guera serán escapados.

6 En estos días de reṿuelta enpezó la gran tenpesta: cada punto se henchía la testa de turcos guereros, de pleitos y reyuelta.

7 Los jiidiós, los deśdichados, estaban muy atagantados de los dacios tan peśgados, que querían vaćiarles los ducados.

8 Por más mal salieron ciertos enemigos y diǰeron: «Los jiidiós, ¿de qué non fueron a la guera, asegún ellos hićieron?».

9 Los jidiós fueron topados en grandes acelados; estonces gastaron ducados por non ser en guera mezclados.

10 Ansí la reṿuelta fue andando hasta que el nemŝí se fue acercando, a la civdad Saray entrando y gente de las dos partes yolando.

11 Día de 10 menahemem ${ }^{36}$ amaneciendo ruido de tiros se enpezó a ir oyendo y turquios $^{37}$ feridos munchos viniendo de lugar de la guera trayendo.

12 La ĝente se escondieron, todos de la muerte fuyeron; los turcos en la calé se recoǵeron, los nemŝís por deredor de la civdad se espandieron.

\footnotetext{
${ }^{35}$ Es decir, a todos los judíos.

${ }^{36}$ Equivalente al 9 de agosto de 1878.

${ }^{37}$ Habríamos esperado turquinos.
} 
13 Las yulés de los tiros iban yolando, de la calé sobre las caśas pasando; los turcos sobre los nemŝís ronĵando, los nemŝís sobre los turcos tirando.

14 Sobre las cabezas iban pasando, las yulés de parte a parte ronjando; la ĝente de la civdad a el Dio exclamando por que la civdad y las famillas que vaya guardando.

15 A las većes pośaban yulés de tiros onde moraban ${ }^{38}$, dañar almas non dañaban, a ningún jidió non tocaban.

16 La guera fue tirando hasta que los turcos se fueron aliviando; al fin de 8 horas escapando se topó la civdad de nemŝís arodeyando.

17 Estonces fue aquedada la guera tan ensañada; a los rebelladores mataron con espada y a los contrarios con plomada ${ }^{39}$.

18 Estonces loores al Dio dieron por lo que sus ojos vieron y del mal que se rihmieron y de toda la taxa que non dieron ${ }^{40}$.

19 Hasta aquí fue sudecido la guera y pleito conocido la Bosna cuando fue prendida del turco ${ }^{41}$, asegún a todos sabido.

${ }^{38}$ Es decir, donde vivían los judíos.

${ }^{39}$ Entiendo que fusilados.

${ }^{40} \mathrm{Al}$ parecer no había dado tiempo a que los judíos entregaran la extorsión que se les exigía para no verse implicados en la batalla.

${ }^{41}$ Es decir, cuando fue arrebatada (prendida, palabra que estropea la rima) a los turcos. 


\section{El incendio de Sarajevo de 1879}

El texto que publico procede de la siguiente fuente única:

- Versión aljamiada publicada en el citado libro de Ya'acob Mošé Ḥ. Altarás, Séfer Źijrón Yerušaláyim (Belogrado 1887) pág. 223 $3^{42}$.- Al final: «Tam, tam».

Poema de Ya'acob Mošé Ḥ. Altaráŝ, compuesto por lo que parecen ser 11 estrofas de cuatro versos monorrimos de diferente medida, que, como decía en textos anteriores procedentes del mismo libro, quizá deba entenderse como prosa rimada. Está escrito en línea seguida sin ninguna partición y también unido sin separación alguna al texto precedente sobre la entrada de los austriacos en Sarajevo en 1878 (núm. 4), aunque por bordar un tema completamente distinto he decidido separarlos.

Como en los dos poemas anteriores, nos refleja ahora también Altaráŝ un acontecimiento histórico no recogido en Entre dos: el incendio que arruinó en 1879 el bazar de Sarajevo.

Veamos en primer lugar el contenido del texto. No bien había pasado un año de la entrada de los austriacos en Sarajevo (vid. núm. 4), estalló un gran incendio en la ciudad (estr. 1) que quemó entre piedras y hierros hasta los bienes mejor escondidos (estr. 2), lo que supuso un gran desastre para los judíos (estr. 3). El fuego cerró el paso a toda escapatoria y tuvieron que refugiarse en el campo (estr. 4). Del tal desastre resultó la ruina general (estr. 5) y a ello se sumó la quema de la sinagoga y de todo cuanto contenía (estr. 6). Nadie pudo salvar nada (estr. 7); pero el autor aconseja paciencia ante las desgracias (estrs. 8-9) y ruega que comuniquen a otros sus palabras, de lo que les estará eternamente agradecido (estrs. 10-11).

Sobre los desastrosos resultados de tal incendio en el bazar de Sarajevo cabe consultar el interesante artículo de Carreras i Verdaguer y Moreno Redón ${ }^{43}$.

Veamos el texto.

1 De este paso de guera anotado ${ }^{44}$

vos contaré más qué fue pasado;

${ }^{42}$ Vid. nota 2 supra.

${ }^{43}$ Carles Carreras i Verdaguer - Sergio Moreno Redón, «Los procesos de modernización en Sarajevo: La incierta dirección de la flecha del tiempo», Anales de Geografía 27/1 (2007) págs. 29-44: pág. 34: fuego en el bazar, que he consultado on line.

${ }^{44}$ Se refiere al texto anterior (núm. 4) sobre la entrada de los austriacos en Sarajevo. 
después de un año ajustado ${ }^{45}$ este lugar, Saray, fue el rob quemado.

2 Un fuego grande fue salido que non lo tuvo visto ningún nacido, que fue quemado afilú bien escondido entre fieros y piedras deretido.

$3 \ll$ «Guay, guay!» dećir pudimos, que bienes de jidiós quemar vimos; todas caśas y boticas que tuvimos, todo en este fuego lo pedrimos.

4 La lunbre grande fue espandida en entrada y salida, solo lugar de muestra fuyida fue por los canpos espandida.

5 Los ricos se enflaquecieron, los benonim se enprobecieron, los más flacos se destruyeron ${ }^{46}$ hasta que a esta hora maldijeron ${ }^{47}$.

6 «iGuay, guay!», tanbién dijimos sobre la pasada hora: «¿qué nacimos?» ${ }^{48}$, cuando el lugar santo quemar vimos: bet hakenéset con los sefarim que tuvimos.

7 Ningún honbre criyado non pudo él ser acercado ${ }^{49}$ por que seya su bien escapado ${ }^{50}$ siendo el fuego de 4 partes fue arodeyado.

${ }^{45}$ No sé si hay que entender ajustado como la expresión jsp. más frecuente por ajusto 'además, para colmo de desgracias, para complicar las cosas' (cfr. fr. ajouter 'añadir'); o como 'justo', para indicar que el incendio se produjo en agosto de 1879, es decir, un año después de lo narrado en el texto anterior.

${ }^{46} \mathrm{El}$ autor alude expresivamente a cómo afectó el desastre a cada una de las tres clases sociales: ricos, burgueses (benonim, hb. בנונים 'medianos') y pobres.

${ }^{47}$ Es decir, hasta el punto de que maldijeron aquella hora.

${ }^{48}$ Entiendo que lo que quiere decir es que exclamaron ¿para qué hemos nacido? cuando ven que la sinagoga se ha quemado, de ahí mi puntuación.

${ }^{49}$ Es decir, acercarse.

${ }^{50}$ Es decir, las personas no pudieron acercarse a salvar sus bienes. 
8 Grandes son las deśgracias que tuvimos con munchas ansias; ansí seyan las ganancias topados con gustos y sin ansias ${ }^{51}$.

9 Para el honbre es la pacencia como entre amigos cencia, lo escapó de mal y ansia y le traye paz y cencia.

10 Hermanos míos queridos, seed con mis hablas atrevidos y cuando soš amigos recoǵidos trayed mis hablas en oyidos ${ }^{52}$.

11 Y yo vo lo regraciaré y a todos mis hermanos bendećiré hasta que yivir viviré ${ }^{53}$ y después de mi muerte, si de mí miśmo sabré ${ }^{54}$. Tam Tam

\section{Dios proteja a Abdul Hamid}

El texto que publico procede de la siguiente fuente única:

- Versión aljamiada publicada en el periódico de Salónica El Avenir 1/4 (miércoles 11 tebet 5658 / 5 genayo 1898) pág. 5b.- Cabecera: «A la ocaśión del aniversario de nacimiento de muestro mañánimo sultán que será fiestado alḥad prósimo en todas las civdades del Imperio inseramos el himno sigüente que mos adrezó muestro amigo se' Habacuc».- Precede al texto la indicación de: «Cante (1)», llamada de nota que se resuelve al final del texto diciendo: «(1) El que deśea embeźar el aire de este cante se adrece a señor Šonina nR"u, director de la escola Kalamariá».

Poema de «Habacuc» -la firma al pie del texto-, formado por 4 estrofas que son pareados emparejados y, al parecer, según lo que hemos anotado arriba, destinado al canto.

${ }^{51} \mathrm{El}$ autor desea que las ganancias sean tan grandes como las pérdidas, encontrándose (topados) felices y sin preocupaciones.

${ }^{52}$ Es decir, cuando estéis reunidos (recogíidos) con amigos, contadles mis palabras.

${ }^{53}$ Es decir, mientras tenga vida.

${ }^{54}$ No deja de resultar curioso para un judío esa desconfianza que parece mostrar el autor sobre si va a saber algo de él mismo cuando muera. 
Se trata de un texto inédito que, si lo hubiera encontrado en su momento, debería haber figurado en Entre dos (cap. 7 aprt. D.2, titulado «Loas al autócrata: aniversarios de Abdul Hamid», núms. 49-51). Como los citados núms. 49-50 de Entre dos se escribieron para festejar el 56 cumpleaños de Abdul Hamid II y el autor que se firma bajo el seudónimo de «Habacuc» es el mismo que también aplaude al sultán en el texto que edito en Entre dos (núm. 51).

Esto es lo que nos dice el empalagoso poema. Los judíos, que se sienten otomanos, alaban al sultán (estr. 1) que ama a sus fieles súbditos y que protege las artes y la cultura (estr. 2). La nación entera ruega que Dios proteja a tan magnífico señor (estr. 3) que solo busca el bien.

Repito aquí las palabras que en Entre dos decía al respecto de estos poemas laudatorios a Abdul Hamid (págs. 370-371):

[...] y lo primero que hay que resaltar es una característica común a todos ellos: la veneración por la figura del sultán de la que hacen gala. No cabe esperar otra cosa: los directores de periódicos, sabiéndose en el punto de mira de la vigilancia represiva de Abdul Hamid e impedidos de publicar ni una coma sin el debido permiso de la censura, eran los primeros en apresurarse a expresar en las páginas de sus publicaciones los elogios de rigor, so pena de graves complicaciones, una de las cuales podía ser la del cierre de la empresa. Si el elogio era moneda común en todo momento, aún lo sería más en las mencionadas señaladas fechas [cumpleaños y subida al trono], afanándose los publicistas en hacer solemnes declaraciones de principios en las que mostraban la más absoluta adhesión al soberano.

Veamos el laudatorio texto.

1 Nos, osmanos, loor alzamos, bendićiendo non cansamos ${ }^{55}$, a nuestro mañánimo sultán, con juusticia, gracia podestán.

2 Súditos fieles aquerencia ${ }^{56}$, artes y mestieres proteja con cencia; todos en estudio adelantan gracias a cuidado del sultán.

3 Padišah graciośo, gran señor potente, pastor bien que guía su pueblo contente,

\footnotetext{
${ }^{55}$ Es decir, no nos cansamos de bendecir.

${ }^{56}$ Claro, porque a los no fieles se los cargaba.
} 
con fervor demanda todo el vatán (patría):

«¡Dio!, proteǵe siempre a nuestro sultán».

4 Sultán paćiguośo, que gracia inculca, todo piadośo, por el bien esculca; bendición del cielo a el padišá. ¡Gaźí sultán Hamid, choc yašá!

\section{El Dios de la salvación}

El texto que publico procede de las siguientes dos fuentes únicas:

- A: Versión aljamiada publicada en el librito Cante muevo por muestro gran rabino ḥ” $r$ Ya acob Meír $n R$ ” $u$ [...] traído a la imprimería meźo Ya‘acob Abraham Yoná [...].- [Sumario en cubierta:] «[...:] 5) Un cante del se' Sa‘adi Haleví 'a'h».- ([Pág. 15:] Sofía: Imprimería de Rahamim Šimonov y comp’, 1908) pág. 16.- Cabecera: «Simán: "Sa‘adi Halevî"» [Baecs núm. 190c] ${ }^{57}$.

- B: Versión manuscrita en el Ms. Habib (Oriente ca. 1910) ${ }^{58}$ h. 30r.- Cabecera: «Se canta en la ỵoź de "Trilinomí manulami", "\$.

Copla compuesta por 7 sextillas de rima aaabba, los vs. 4 y 5 de pie quebrado; la versión manuscrita omite la estr. 6. Según se anuncia en la cabecera, tiene acróstico con el nombre del autor: «Sa'adi Haleví Ašquenaźí» (estrs. 1-6). La primera palabra de cada estrofa en letras cuadradas y en estrofas 5-6 separadas del texto por un guión; las estrofas separadas por una rayita centrada.

En su momento decidí no incluir este texto en Entre dos, ya que no conseguí desentrañar el asunto al que se estaba refiriendo Haleví. Pero ahora he decidido

${ }^{57}$ Abrev. del libro de Elena Romero, Bibliografía analítica de ediciones de coplas sefardíes, Intr. Iacob M. HASSÁN (Madrid 1992).

${ }^{58}$ Manejo fotocopia del ejemplar de Yeshiva University (New York) YU JHC (1L).

${ }^{59}$ Escrito טרילינומי מאנולאמי. Agradezco a mi buen amigo Pedro Bádenas las siguientes explicaciones sobre etimología y significado. Se trata seguramente del íncipit o del estribillo

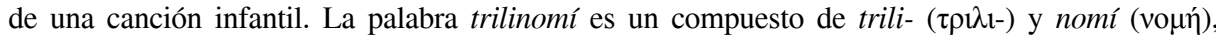
correspondiendo el primer elemento a la voz onomatopéyica indeclinable y neutra trili $(\tau \rho i ́ \lambda 1 \alpha)$, aquí probablemente con el significado de 'repetición muy rápida de sonidos con intervalos de un tono o un semitono'; y el segundo nomí 'donativo, aguinaldo', sustantivo que deriva del verbo vé $\mu \omega$ 'lo que se reparte o distribuye'. Por lo que se refiere a manulami puede tratarse de un derivado de manuli ( $\mu \alpha v o v ́ \lambda \imath$ ) 'chico muy joven y guapo', con un sufijo hipocorístico. Propone Bádenas que la frase podría traducirse por algo parecido a: «Al son de "Tararí, chiquito bonito, un regalito"». 
asumir mi ignorancia y poner el texto en circulación para que otros puedan hacer lo que yo no he sabido. Esto es lo nos cuenta el abstruso texto.

El autor eleva sus alabanzas al Dios de la salvación (estr. 1) para que todos recuerden los males sucedidos en años pasados o en los últimos años (estr. 2). Al ver quién ha sido despedido o a quién le han dado licencia para hacer algo, todos se preocuparon mucho, ya que el asunto afectó tanto a los ricos como a los de clase media (estr. 3), y sin esperarlo estuvieron todos a punto de ser prendidos en la red, pero Dios los libró del peligro (estr. 4), por lo que deben darle gracias tanto judíos como gentiles (estr. 5). Todo el mundo estará encantado dando vítores cuando la vela (¿bandera?) azafrán triunfe (estr. 6). Dios ha premiado a Israel y todos lo han alabado (estr. 7).

Muy poco puedo decir al respecto. Cabe recordar que, según nuestros datos, el popular escritor de Salónica Sa'adi Haleví (1820-1903) ${ }^{60}$ había fallecido unos años antes de la fecha de publicación de esta copla (1908). Así pues, el asunto del que nos habla debe ser anterior a 1903, pero ignoro cuánto, y el no tener un asidero temporal es uno de los graves problemas para la identificación del acontecimiento. Tampoco me aclaran nada los pocos datos que sobre el hecho narrado aparecen en el poema, expresados mediante meras alusiones: que alguien ha sido despedido - ide un puesto político?-o ha obtenido licencia para hacer algo (estr. 3; vid. nota 63 infra), al parecer no bueno; que el mal se hundió en el mar, lo que también puede ser una imagen poética, y que el problema afectaba tanto a judíos como a gentiles (estr. 5); y la alusión a la «vela azafrán», en donde no sé si cabe entender vela como las de los barcos o como bandera, y también se me escapa el sentido del color azafrán (estr. 6).

Veamos el texto; en mi edición anoto entre dobles corchetes las variantes de la versión manuscrita, que a diferencia de la impresa, no tiene en letras cuadradas las palabras iniciales de estrofa.

$1 \quad$ [Sa $a$ Suba al Dio mi oración

[[con]] hablas de alabación ${ }^{61}$

con muestra [[muncha]] buena inteción

de estimar

y de amar

a el Dio de la salvación.

\footnotetext{
${ }^{60}$ Vid. Elena Romero «Dos "coplas del fuego" sefardíes en busca de autor», Sefarad 65 (2005) págs. 127-170.

${ }^{61}$ Parece mejor la formulación del manuscrito al iniciar el verso mediante con.
} 
$2\left[{ }^{6} a\right]^{6}$ Osé niflaot ${ }^{62} \sin$ contar siempre ternemos que enmentar, añadas fue de [[muncho mos hiźo]] espantar; lo que pasó y trespasó lo diremos con buen cantar.

3 [d]De ver quén tuvo el rusat ${ }^{63}$ les apretó muncho quiesat; a todos mos fue gran fesat ${ }^{64}$ que apretó, non [[no]] apartó, tanto alayé como [[y a]] efsat [[evsat $]]^{65}$.

4 [i]Llevimos mal sin lo pensar que la red mos iba cazar; presto lo hiźo el Dio pasar.

Él es raḥamán y neemán, el séjel non [[no]] puedo [[puede] $]^{66}$ alcanzar.

5 [Haleví]Albicias [[Alvicias] $]^{67}$ demos a el Dio que presto Él mos respondió, el mal en la mar [[om. mar]] ${ }^{68}$ lo hundió [[fundió]]; loaremos [[aloaremos]], alabemos tanto goyim como juudió [[jidióó]].

${ }^{62} \mathrm{Hb}$. עושה נפלאות ‘hace maravillas’, es decir (vs. 2a-b), siempre tendremos (ternemos) que recordar (enmentar) que Dios hace maravillas sin cuento.

${ }^{63}$ No sé cuál de los dos sentidos tiene aquí tc. ruhsat si 'licencia, permiso para hacer algo' o 'despido, dimisión'.

${ }^{64}$ Vid. Joseph Nehama, Dictionnaire du Judéo-espagnol (Madrid 1977) s.v.fesád 'événement curieux, qui intrigue, qui est digne d'être raconté'; cfr. tc. fesat 'mal, daño, agravio'.

${ }^{65}$ Cfr. tc. alâye 'lugar elevado, altura', aquí 'de clase alta', es decir, los más ricos, y tc. evsat 'medio; mediano', es decir, de clase media, los menos ricos.

${ }^{66}$ Parece mejor la formulación del manuscrito con puede en $3^{\mathrm{a}}$ persona para decir que el entendimiento (séjel) no puede alcanzar la grandeza de Dios.

${ }^{67}$ Juego de palabras con el apellido del autor, más claro en el manuscrito, donde albicias se escribe con vav.

${ }^{68}$ La versión manuscrita, al omitir mar, deja el verso sin sentido. 
6 «Aškenaźi ${ }^{69} »$, todos dirán,

«Eviva», mos responderán;

en ver la vela azafrán

se aflojen

y la aḅaǰen,

gusto el mundo tomarán [[om. estr.]].

7 Supimos tanto bien que Él ${ }^{70}$

gualadronó a Yisrael;

todos dieron [[dićen]] šébaḥ $\mathrm{laEl}^{71}$

de piadad [[que perdonó]]

y humanidad [[y aḅandonó]];

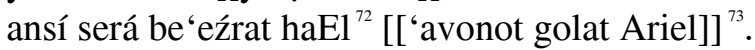

Si bien no he podido aclarar muchas cosas sobre el contenido del texto, lo que sí puedo poner de relieve es, una vez más, cómo Ya'acob Yoná, editor del Cante muevo, hizo uso y abuso del poema de Sa'adi Haleví ${ }^{74}$. Hacia 1909 Yoná publicó una copla que edito en Entre dos (núm. 68, págs. 434-435) bajo el título de Un crudo invierno, y que por estar destinada a la fiesta de Šabu'ot, se formula en tercetos monorrimos, metro habitual de las coplas de tal festividad. Como decía en Entre dos (pág. 434), probablemente Yoná está aludiendo en su poema a la fracasada intentona de golpe de estado por parte de Abdul Hamid del 13 de abril de $1909^{75}$.

Pues bien, en tal copla de Yoná encontramos las siguientes formulaciones que resultan ser un trasunto de la de Haleví que aquí edito, en las que hábilmente se ha cambiado el sistema métrico de ese original (indico entre corchetes los versos copiados):

${ }^{69}$ Juego de palabras entre el segundo apellido del autor, escrito אשכנזי, y la invitación a beber de tc. aşkınıza 'a tu salud'.

${ }^{70}$ Palabra que también puede entenderse como hb. אל El 'Dios'.

${ }^{71} \mathrm{Hb}$. שבח לאל 'alabanza a Dios', que en la formulación del manuscrito quizá habría que traducir como 'alabado sea Dios'.

${ }^{72} \mathrm{Hb}$. בעזרת האל 'con ayuda de Dios'.

${ }^{73}$ Hb. עוונות גולת אריאל 'los pecados de la diáspora de Ariel'; el manuscrito cambia completamente la formulación y el sentido de los tres últimos versos -que habría que puntuar «que perdonó / y aḅandonó / 'avonot golat Ariel»-, para decir ahora que Dios ha perdonado y olvidado (aḅandonó) los pecados de la diáspora judía.

${ }^{74}$ Otros ejemplos de lo mismo pueden verse en mi artículo en colaboración con Dora MancheVA, «Historia de un plagio: las coplas sefardíes Los tiempos modernos, de Sa aadí Haleví, y El lujo y la escasez, de Ya'acob Yoná», Sefarad 67 (2007) págs. 437-468.

${ }^{75}$ Vid. Romero Entre dos cap. 9 págs. 437-440. 
1 Alabemos a el Dio con hablas de alabación [= 1b], con toda muestra buena inteción [= 1c] de estimar y de amar a el Dio de la salvación [= 1d-f].

2 Bastantes nisim mos hace que non se vienen a contar [=2a], siendo esta añada mos vino a'spantar [ $[=2 \mathrm{c}]$; lo que pasó y trespasó lo diremos con buen cantar [=2d-f] [...].

4 De ver que hay largo tiempo que apretó el quiesat [= 3a-b], que a grandes y a chicos mos fue gran fesat $[=3 \mathrm{c}]$, que apretó bastante, tanto a ilayé como evsat $[=3 \mathrm{~d}-\mathrm{f}]$.

\section{Caos comunitario en la Constantinopla de 1922}

El texto que publico procede de la siguiente fuente única:

- Versión aljamiada publicada en el periódico de Constantinopla El Juguetón 14/1 (martes 14 adar 5682 [= 14 mar. 1922, Purim] págs. 4b-6a.- Cabecera: «Cantes de Purim» [no en Baecs].

Copla inédita, probablemente del director del periódico, Eliyá Carmona, formada por 22 estrofas octo-hexasílabas, con acróstico alefático, marcadas las letras que lo forman en cuadradas y separadas de su palabra. El texto abunda en errores tipográficos que corrijo sin avisar.

La copla, que mayoritariamente se ocupa de asuntos internos de la comunidad, se escribió en un momento de alto el fuego en la guerra que en el interior de Anatolia mantenían turcos y griegos, habiendo quedado estabilizado el frente en septiembre de 1921 (Entre dos pág. 616), mientras que Constantinopla seguía ocupada por las potencias occidentales (Entre dos págs. 613 y 615). Tras la falta de acuerdo en la conferencia celebrada en París (22 mar. 1922), la guerra se reinició prologándose hasta principios de septiembre (Entre dos pág. 629).

Como ya decía en Entre dos (pág. 617), de aquellos años apenas he encontrado textos que me informen sobre la situación de los judíos de Constantinopla. En Entre dos (pág. 23) no tuve en cuenta esta copla, ya que allí decía que no era mi propósito ocuparme de los poemas «muy numerosos, publicados especialmente en la prensa periódica sefardí, sobre temas exclusivamente comunitarios», lo que es casi el caso de la presente copla, pues en la última estrofa se hace mención de la aludida guerra. Sin embargo, ahora, tanto por oír un poco la voz de los sefardíes de Constantinopla en ese conflictivo año de 1922, como por no dejar en el tintero una copla de las que 
he denominado en otra ocasión «de por Purim» ${ }^{76}$, he decidido ocuparme de ella.

Esto es lo que nos cuenta en un permanente lamento y crítica de la administración comunal, lo que se subraya mediante el ¡ay! con que se finalizan las estrofas, si bien, inopinadamente, ya que no hay nada que celebrar en su contenido, la estr. 8 finaliza con un ¡bien!

Empieza la copla con un verso (1a) que es remedo de la clásica de Purim La historia de Amán y Mardoqueo (Baecs núms. 1a y ss.) para seguir criticando el alto precio que la administración comunitaria ha fijado para los panes ázimos de Pascua (estr. 1). A pesar de los esfuerzos del gran rabino, que por entonces era Hayim Bidjarano, quien ocupó el puesto de gran rabino en funciones desde 1920 hasta su muerte en $1931^{77}$, la directiva comunitaria es un desastre y nadie puede fiarse de sus miembros (estr. 2), quienes, a pesar de que las arcas comunales han tenido ganancias, han gastado de más, especialmente por los sueldos que han cobrado los directivos (estr. 3). Se alude después a los debates de la «Constituente», que probablemente alude a la sesión constituyente de la nueva directiva comunitaria, ya que no creo que se refiera al Parlamento convocado en Constantinopla en enero de 1920 (Entre dos pág. 615), y menos aún a la Constitución proclamada el 20 de enero de 1921 por la Gran Asamblea Nacional con sede en Ankara, presidida por Kemal Atatürk (Entre dos pág. 616), cuyos efectos no habían llegado a la capital; tales debates fueron negativos para los judíos y llevaron a presentar la dimisión a diez directivos comunales, criticando Carmona que solo dimitieran diez, mientras los demás se aferraron a sus puestos (estr. 4). Alude después a los ingresos que la comunidad recibe de las donaciones (estr. 5), quejándose también del paro de las obras del hospital, a pesar de contar con los materiales de construcción comprados por el benefactor Cadorí (estrs. 6-7). Exige que se formen rabinos modernos (estr. 8) y que se controle a las escuelas rabínicas (estr. 9), así como que se ayude a viudas y huérfanos y a los pobres padres que no pueden alimentar a sus familias (estrs. 10-11). Como no basta el buen trabajo de la comisión de caridad y el dinero que llega de América, hay que buscar otros recursos y fuentes de ingresos (estr. 12), admitiendo el autor que la causa de tantos males la tiene la actual crisis económica que ha paralizado el mercado (estr. 13). Alude después al desastre que ha significado el intento de construcción de una escuela, al parecer en el barrio de Balat: las obras han quedado paradas, habiéndose criticado el asunto en la prensa

${ }^{76}$ Vid. la Introducción de mi libro $Y$ hubo luz y no fue tan buena: Las coplas sefardíes de Purim y los tiempos modernos (Barcelona 2008).

${ }^{77}$ Vid. Baruh B. Pinto, What's Behind a Name (Istanbul 2002) pág. 178, núm. 403; y Abraham Galante, Histoire des Juifs d'Istanbul, 2 vols. (Istanbul 1941-1942): vol. I, págs. 90, $92,106,143-147$ y 152 y 215 ; y vol. II, págs. 106, 133 y 165. 
local (estrs. 14-16). Ahora que se acerca la fiesta de Pésah, pide que todos ayuden a los más pobres y a las organizaciones de caridad (estrs. 17-18). Recomienda que se paguen a tiempo los impuestos (estr. 19), así como que se brinde ayuda a los emigrantes, sea cual sea su religión, acusando a sus correligionarios de chovinistas (estr. 20): Acaba el poema pidiendo que todos recen a Dios por el final de la guerra y por que les dé fuerza para afrontar el porvenir (estr. 22).

No es el primer texto de Carmona en el que pone en solfa asuntos comunitarios y da buenos consejos sobre cómo solucionarlos; tal es el caso de su poema que titulo Panegírico de rabí Hayim Nahum (Entre dos cap. 8, núm. 67, págs. 421-431), publicado hacia 1909.

Veamos ya el texto.

1 [']Empezar quero contar hechos de este año: del kolel y la maŝá fue a nuestro daño, esto fue un engaño por el Gran Raḅinato; a todos mos encantó: grušes trenta y cinco ${ }^{78}$, probe como rico. ¡Ay!

2 Ba'avonot nuestra nación ${ }^{79}$ va en decadencia, mucho laźra por el bien y su eminencia; no quedó pacencia en los reǵidores, entre sus diriǵidores no hay quen los guía ni que[n] los confía. ¡Ay!

3 Ganancias buenas: una en todas las entradas; los gastes fueron muchos y grandes meśadas no fueron miradas como es el menester; no se puede admeter obras $^{80}$ sufriendo y otros riendo. ¡Ay!

4 Debates grandes hubo en la Constituente, lo que por nuestra nación fue muy insolente; esto fue cavśante a dar la dimisión la viejáa administración: diez dimisionaron, otros se trabaron ${ }^{81}$. ¡Ay!

${ }^{78}$ Lo que a Carmona le parece un precio muy caro por los panes ázimos imprescindibles en la fiesta de Pésaḥ.

${ }^{79}$ Se refiere a la «nación judía» y en este caso a la comunidad de Constantinopla.

${ }^{80}$ Habría esperado unos frente al posterior otros.

${ }^{81}$ Entiendo que hay que entender se trabaron como se abstuvieron, se aferraron a sus puestos. 
5 Hecdešot de la nación ${ }^{82}$ ¿por quén administrados?: del budĝé del Mejlís ${ }^{83}$ deben ser quitados ${ }^{84}$ y administrados por sus comisión y no la nueva administración: que ella se ocupe y que no uśurpe. ¡Ay!

6 Venid, queridos hij́os, mirad la deśgracia: la fragua del hespital quedó en estancia ${ }^{85}$; es muy grande ansia no pueder parvenir segurar el avenir, tomar la esencia por su eminencia ${ }^{86}$. ¡Ay!

7 Źemán mucho ya pasó y de el empleo ${ }^{87}$, material de construcción vino con coreo; esto es muy feo enfrente del donador, Cadorí $^{88}$, el rehmidor de cavśos manciośos y muy contaǵiośos. ¡Ay!

8 Hajamim de nuestro dor ¿qué estáš haćiendo?, la ley santa del judió se va deperiendo; consultad los ricos, preparad al menos hajamim bien modernos, no restar sin capos, codreros en campos. ¡Bien!

9 Tomad en vuestras manos un program valible, questiones de reliĝión reglad, si posible, controlad de cerca y las yešibot

lo que haće el kabod de la ley bendicha que está en desdicha. ¡Ay!

${ }^{82}$ De estas hecdešot ya se ocupaba Carmona en el poema aludido supra Panegírico de rabí Hayim Nahum (vid. Romero Entre dos págs. 424-425, y núm. 67, págs. 425-431, estrs. 99-102).

${ }^{83}$ Tc. meclis 'consejo'; entiendo que se refiere al llamado Meclis Cismani 'Consejo Laico' o 'Consejo Comunal' del que me ocupaba en Entre dos cap. 8 pág. 426 nota 70.

${ }^{84}$ Opina Carmona que esos ingresos no deben ir a parar al presupuesto del Consejo Comunal.

${ }^{85}$ Entiendo que quedó estancada.

${ }^{86}$ No entiendo el sentido del verso ni cuál es el papel que juega el aludido gran rabino.

${ }^{87}$ Quizá quiera decir que ha pasado mucho tiempo (źemán) desde la compra (empleo) del material de construcción que se menciona en el verso siguiente.

${ }^{88}$ Debe tratarse de Elí Cadorí, filántropo de Constantinopla; vid. Galante Istanbul vol. II, págs. 161-162. 
10 Yetomim y almanot siempre van llorando de no haber en la nación quen los va mirando ${ }^{89}$; día cada día mos va ${ }^{90}$ pujando

y ansias van criando: entre los forestos $^{91}$ hay munchos de estos. ¡Ay!

11 [K]Cavanés y meanés todas están llenas de probes bené tobim ${ }^{92}$ de famillas buenas con sus caras pretas ${ }^{93}$ sin pueder topar

los medios para tapar bocas de sus niños; de piadad son diños. ¡Ay!

12 La comisión de socoros muncho va haćiendo, de los judiós de América sumas van viniendo; esto, no puediendo aḅastecer, resurzas cale crecer en nuestras civdades munchas cuantidades. ¡Ay!

13 Malhor grande ya nos fue estas criśas, sin ellas iba haber y munchas surpriśas, cuantas entrepiśas puedíamos tener $\mathrm{y}$ en el menester ${ }^{94}$ donos importables de munchos notables. ¡Ay!

14 Nunca se tuvo oyido ni este afito: las parás de la nación gastar sin profito; fraguar una escola a sus parecer, ellos pudieron haćer un plano de palacio en chico espacio ${ }^{95}$. ¡Ay!

\footnotetext{
${ }^{89}$ Es decir, quien se ocupe de ellos.

${ }^{90}$ Hubiera esperado van (como en verso siguiente), relativo a los huérfanos y viudas de v. $10 \mathrm{a}$.

${ }^{91}$ Es decir, los forasteros; quizá esté aludiendo Carmona a los muchos emigrantes y desplazados por causa de la guerra en Anatolia.

בני טובים. lit. 'hijos de buenos', que supongo que aquí significa 'buenas gentes' y no 'de buena familia', lo que resultaría reiterativo con lo que se dice en el verso siguiente.

${ }^{93}$ Es decir, tristes, con expresión desesperada.

${ }^{94}$ Es decir, en los casos de necesidad o en lo relativo a aliviar la pobreza. escuela.

${ }^{95}$ Parece decir que los planos previstos parecían los de un palacio y no los de una pequeña
} 
15 Sin cuenta y sin hẹešbón liras se gastaron, por mancanza de saber y la mitad quedaron ${ }^{96}$; ellos ya penaron para parvenir y dejar un suvenir: mancanza de experienza trujo decadencia. ¡Ay!

16 'Ayin hará' les tocó a los que se ocuparon, en la prensa de Estambul ya los criticaron; el lugar ceraron sin continuar por esperar a fraguar ${ }^{97}$; Balat, caśal modesto ${ }^{98}$, trujeron en esto. ¡Ay!

17 Purim vino de aribar ${ }^{99}$ y Pésah en la mano ${ }^{100}$, la vida y los días pasaron en vano; venga de la mano ${ }^{101}$ a haćer el bien para serle el sostén de munchas famías que no comen días ${ }^{102}$. ¡Ay!

18 Sedacá y donaciones demos de contino, hespital, orfelinato no salga del tino ${ }^{103}$, a obras ${ }^{104}$ y escolas cale ayudar, sus deficito cumular ${ }^{105}$ es deber del rico, grande como chico. ¡Ay!

19 Queŝabot y taxaciones deben ser pagadas, por el bien de la nación no ser atraśadas;

${ }^{96}$ Quizá quiera decir que a la mitad de la construcción se quedaron sin dinero.

${ }^{97}$ Quizá quiera decir que las obras se interrumpieran sin esperanza de reanudarlas.

${ }^{98}$ Lugar donde se estaba construyendo la fallida escuela; nombre de un barrio de Constantinopla, en la margen izquierda del Cuerno de Oro, que por entonces sería un pueblecito (caśal).

${ }^{99}$ Calco del fr. venir d'arriver 'acabar de llegar'.

${ }^{100}$ Es decir, a la vuelta de la esquina, ya que un mes separa ambas festividades. La expresión remeda la de una cancioncilla festiva de Purim que dice «Purim, Purim lanu ('tenemos') / Pésaḥ en la mano».

${ }^{101}$ Nehama Dictionnaire s.v. venír recoge la expresión «todo le vyene de la mano» que explica 'il est très ingénieux [...]', es decir, en nuestro caso, que se las ingenie, que busque la forma para hacer lo que se dice luego.

${ }^{102}$ Es decir, que hace días que no comen.

${ }^{103}$ Es decir, sin olvidar (salga del tino) el hospital y el orfelinato.

${ }^{104}$ Se refiere a las asociaciones de beneficencia.

${ }^{105}$ Mi falta de conocimientos de economía me impide entender qué es lo que se aconseja (cumular, fr. cumuler) hacer con el déficit. 
todas las añadas, si no pueden pagar,

las devdas cale amortiźar,

no esperar a ser pasajeros, otomanos y estranjeros ${ }^{106}$. ¡Ay!

20 Raḥamanut cale haćer con los emigrados, por ellos no cale ser lejos y guadrados ${ }^{107}$; judiós y paganos sin diferencia, esto obliga la concencia:

proteja al foresto, ¡que no vengas en esto! ${ }^{108}$. ¡Ay!

21 Čhoviniśmo por nośotros es la grande llaga; nacional y liḅeral ${ }^{109}$ el bien que le haga, todos tienen paga del universo ${ }^{110}$; quen es de buen senso esto lo axepta ${ }^{111} \quad$ y no lo detesta. ;Ay!

22 Tefilot siempre haćer muy bueno ya era que el Dio de los cielos cere esta guerra ${ }^{112}$; es la hora buena de mirar el avenir y no querer revenir a la indiferencia, obrar con pacencia. ¡Ay!

\section{La invencible crisis de 1926}

El texto que publico procede de la siguiente fuente única:

- Versión aljamiada publicada en el periódico de Salónica El Riśón 1/12 (viernes 14 tišrí 5687 / 22 setembre 1926) pág. 2b-c.- Cabecera general: Los piźmonim de Sukot; cabecera propia: Yom guilá, yom guilá ['Día de júbilo, día de júbilo'].

${ }^{106}$ Parece decir que hay que cumplir las obligaciones con el estado, ya que no se puede ser a la vez ciudadano otomano y extranjero.

${ }^{107}$ Vuelve a insistir Carmona en la ayuda a los emigrantes, con los que no se puede uno comportar con lejanía y reserva.

${ }^{108}$ Frase desiderativa para decir que ojalá no se vean nunca en las miserias de la emigración.

${ }^{109}$ Es decir, tanto sean de ideas nacionalistas como liberales.

${ }^{110}$ Insiste Carmona en que la ayuda debe prestarse tanto a judíos como a no judíos.

${ }^{111}$ Escrito אקסיפטה; cfr. fr. accepter 'aceptar'.

${ }^{112}$ Ya hemos dicho en nuestro comentario supra que la guerra no acabó definitivamente hasta varios meses después. 
Poemilla anónimo e inédito que consta de dos estrofas de 4 versos con tendencia octosilábica y rima $a b a b$, seguidos de un estribillo de dos versos monorrimos.

Bajo la cabecera general de Los piźmonim de Sukot, publica el periódico 7 poemas que parodian otros hebreos propios de esa fiesta. El nuestro, segundo de la serie, dice lo siguiente.

Con la terrible crisis, resulta cada vez más difícil ganar algo de dinero, lo que se agrava ante la llegada del invierno (estr. 1). Los males vienen por la devaluación de la moneda, que nos tiene consumidos (estr. 2).

No creo necesario repetir aquí lo que ya decía en Entre dos (cap. 16) sobre la grave crisis económica que azotaba a Grecia en aquellos momentos y que venía arrastrando desde hacía años. Para colmo de males, en septiembre de 1925 y mediante un golpe militar, se hizo con el poder el general Ceodoros Pángalos, quien, en enero del año siguiente suspendió la Constitución y asumió dictatorialmente el gobierno, autonombrándose presidente de la República tras una parodia de elecciones. Partidario de la fuerza, gobernó con tal dureza que el 12 de agosto de ese año estalló un nuevo pronunciamiento militar, encabezado ahora por el general Yorgos Condilis, quien convocó elecciones generales para el 7 de noviembre de ese año.

Con esa situación de fondo no es de asombrar la realidad económica del país a la que alude nuestro breve pero expresivo texto.

$$
\begin{aligned}
& \text { El ganar está muy someno }{ }^{113} \text {, } \\
& \text { es belá y, con alḅor, } \\
& \text { en entrada de invierno }{ }^{114} \\
& \text { la vida no da sabor. } \\
& \text { Con la criś, con la criśs } \\
& \text { ya mos cayó la nariź }{ }^{115} \text {. }
\end{aligned}
$$

${ }^{113}$ Nehama Dictionnaire s.v. soméno recoge la expresión «el jazino está muy someno» que traduce 'le malade va très mal, son état empire'; aquí el empeoramiento se aplica con el mismo sentido al hecho de ganar dinero.

${ }^{114}$ Es decir, que esperan angustiados la llegada del invierno, por los gastos extra que tal estación trae consigo (compra de carbón y de leña, de ropa de abrigo, etc.). La palabra alḅor (v. 1b), escrita en mi texto con bet sin tilde, creo que corresponde a los alvóres recogidos por Nehama Dictionnaire y a la expresión «estar con alvores» que explica 'avoir de forts battements de coeur, [...] des pressentiments pénibles [...]'.

${ }^{115}$ Nehama Dictionnaire s.v. naríz recoge la expresión paralela de «estar con la nariz enriva un mušo ['labio']» que explica 'avoir le nez affaissé sur la lèvre supérieure en signe de bouderie, de mécontentement'. 
$2 \mathrm{Si}^{116}$ la drahme se aroba,

la londra ver aḅajar;

¡artic!, mos entró ḩaroba ${ }^{117}$

y mos supo deślečhar ${ }^{118}$.

Esta criśs, esta criś,

ya mos entró la... lombriź ${ }^{119}$.

\section{La pérfida Albión de 1939}

El texto que publico procede de la siguiente fuente única:

- Versión aljamiada publicada en el periódico de Salónica Mesajero 4/1069 ([5 mar. 1939]) pág. 3 [?] ${ }^{120}$ col. dch.- Cabecera general: «Muestras complas de Purim».- «[...] a los sones de "Alabar quiero al Dio...."» ${ }^{121}$ [no en Baecs].

Copla inédita y anónima que debería haber tenido en cuenta en Entre dos de haberla encontrado a tiempo. Esta formada por 22 estrofas octo-hexasílabas, con acróstico alefático, marcadas las letras que lo forman en cuadradas y separadas de su palabra.

El texto va precedido de una interesante entradilla que nos aclara el acontecimiento histórico al que se refiere. Dice así.

Malgrado la situación escura en la cuala el ĵudaíśmo parece estar fundido, sobre todo con los evenimientos de estos últimos días y con las tristes notencias que deśoluśionan [sic] muestras esperanzas de la Conferencia de la Meśa Redonda por la cuestión de Palestina, este judaíśmo que ya se

${ }^{116}$ Que también podría ser sí de así.

${ }^{117}$ Nehama Dictionnaire s.v. jarróva recoge la expresión «seko como la jarrova» que traduce 'sec, desséché, racorni comme une caroube, en parlant de quelqu'un qui n'a que les os et la peau'.

${ }^{118}$ Es decir, dejar sin fuerzas; vid. Nehama Dictionnaire s.v. deslešádo, deslešarse. Quizá haya que poner la palabra en relación con fr. lâcher 'aflojar' y lâche 'flojo, sin nervio'

${ }^{119}$ Nehama Dictionnaire s.v. lombríz recoge la expresión coloquial «tyene lombrizes» 'il a faim tout le temps'.

${ }^{120}$ Uso una fotocopia con solo la página que contiene el texto, que no está numerada; el número y la fecha del ejemplar del periódico están suplidos a bolígrafo.

${ }^{121}$ Íncipit de la popular copla de Sa'adi Haleví La celebración de Purim (Baecs núms. 79a y ss.), cuya edición crítica he preparado en mi libro Los yantares de Purim: Coplas y poemas sefardíes de contenido folclórico (Barcelona 2011). 
cuićió con las persecuciones en los miles de años del galut, en una fiesta como Purim, que es el símbolo de los mirácolos el pueblo de «Atá bajartanu» ['Tú nos ha elegido', es decir, el pueblo judío] se reśiña con la fey. En la esperanza de ser un día regmido, deǰa al portal de su caśa las amarguras y el más liḅeral, por ataviśmo fuese o porque en su sangre tiene enraigado el fataliśmo oriantal, viene recallentar su alma en la rescaldada de las fiestas, y malgrado todo, se esforza con optimiśmo a esperar días mejores. Por esto, si miśmo no canta ${ }^{122}$, su alma se anima al recodro de la vejé ${ }^{123}$ de los cantes litúrǵicos o de las complas por las cualas las adaptamos hoy a los sones de «Alabar quiero al Dio...»"

Recapitulemos los datos y aclaremos la realidad histórica. El 2 de noviembre de 1917, Lord Arthur Balfour, ministro de Asuntos Exteriores de Gran Bretaña, con el fin de atraerse las simpatías de los sionistas de Europa, se comprometió en carta dirigida a Lord Walter Rothschild a apoyar la constitución de un Estado judío en la por entonces posesión turca de Palestina, cuya administración al acabar la Primera guerra mundial le fue encomendada a Gran Bretaña por la Sociedad de Naciones; se trata de la denominada Declaración Balfour (Entre dos pág. 664). El Mandato británico en la zona, que comprendía en un principio Jordania, Israel y Palestina, duró desde junio de 1922 hasta mayo de 1948; pero en septiembre de ese mismo año 1922 los ingleses deslindaron la parte oriental del territorio con la creación del Emirato de Transjordania, quedando la zona dividida en una suerte de dos Mandatos separados.

En los años 1936-1939 se produjeron violentísimos disturbios en la parte que compartían judíos y musulmanes; se trata de la llamada Gran Revuelta Árabe, liderada por el Gran Muftí Amín al-Husaini, que fue aplastada por los británicos.

Ya desde 1936, con la llamada Comisión Peel, y más tarde, en 1938, con la Comisión Woodhead, los británicos estudiaban la posibilidad de proceder a una partición del territorio en dos estados separados -musulmán y judío-, idea que fue rechazada por los dos pueblos en litigio, y concretamente por parte judía, dado que solo se destinaba a su futuro Estado una pequeña franja costera del territorio.

En 1939 y a la vista de las acciones de Hitler, los británicos cambiaron su postura -si es que alguna vez lo fue- proclive a los judíos, olvidando todos los acuerdos firmados y aprobados desde la Declaración Balfour en adelante sobre la creación de un Estado judío, ya que, ante lo que previsiblemente se avecina-

\footnotetext{
${ }^{122}$ Es decir, incluso si no canta.

${ }^{123}$ Escrito ב'יקיס, probable error tipográfico.

${ }^{124}$ Anotación esta última que va en línea suelta, centrada y en caracteres cuadrados.
} 
ba, se les hizo presente su urgente necesidad de contar con el apoyo árabe en Oriente medio.

Para conseguir sus propósitos, en febrero de 1939 convocaron en Londres la llamada Conferencia de Saint James, también llamada -como dice la entradilla de nuestro texto que hemos visto supra-Conferencia de la Mesa Redonda. A ella acudieron sendas delegaciones, una árabe y otra judía, formando parte de esta última Haim Weizmann, por entonces Presidente de la Organización Sionista Mundial y más tarde primer Presidente de Israel. La Conferencia concluyó el 17 de marzo de 1939 sin alcanzarse ningún acuerdo entre las delegaciones. Como resultado de lo (in)tratado, el gobierno de Neville Chamberlain publicó el llamado Libro Blanco o Libro Blanco de McDonald, por entonces ministro británico de las Colonias, según el cual se acordaba la no división en dos Estados de la zona, la creación de una Palestina única y en el futuro independiente gobernada por árabes y judíos, y en cuanto a estos se les ponían gravísimas trabas a la inmigración -irresponsabilidad injustificable, ya que del amor de Hitler por los judíos ya se sabía bastante para esas fechas- y a la compra de tierras.

Nuestra copla, que rezuma amargura y desilusión, nos dice lo siguiente. Todos los judíos están tristes por el engaño de los británicos, que los han vendido a los árabes en la Mesa Redonda que se está celebrando, convirtiendo en harapos la Declaración Balfour (estrs. 1-3). No han tenido éxito los esfuerzos de Waizmann y de Ben Gurión, pero... el tiempo dirá, ya que siempre ríe mejor quien ríe el último (estr. 4). Hay que tener esperanza (estr. 5) y celebrar la fiesta de Purim en esta ciudad de Salónica, en la que el gobierno trata bien a los judíos (estr. 6).

Sobre quién dirigía en esos momentos la nación griega recordemos lo que decía en Entre dos (pág. 714). El general Ioanis Metaxás, primer ministro desde el 13 de abril de 1936, había decretado el 4 de agosto de ese año, manu militari y de acuerdo con el rey Jorge II, la disolución del Parlamento y, proclamando la ley marcial, tomó las riendas del poder. Aún continuaba Grecia bajo la férrea mano de Metaxás al estallar la Segunda guerra mundial ${ }^{125}$.

Veamos el texto.

1 Está triste el ĵidió del mundo entero, el ingléś mos sacudió, mos hiźo bultero ${ }^{126}$;

${ }^{125}$ En Romero Entre dos cap. 16, núm. 165 (págs. 739-740) puede verse un poema de alabanza al general en el titulado Alabanza al gobierno de Metaxás, publicado en 1938, es decir, un año antes del que ahora edito.

${ }^{126}$ Nehama Dictionnaire s.v. bultéro recoge la expresión «fazer un bultero» que explica 'faire un paquet en y jetant les choses pêle-mêle et le lier à la va-comme-je-te-posse'. 


\section{él mira primero a su interés, mos truǰo aréś aréś ${ }^{127}$, mos subió al pino ${ }^{128}$, ma salió pepino ${ }^{129}$.}

2 Sin quierer salió feraj ${ }^{130}$, mos vendió barato, por contentar al felaj mos hiźo garato y de el Mandato que él prometió vimos que se repintió; no mos se esplica que mos sacrifica.

\section{La declaración Balfur se hiźo hạandrajo, presto lo hiźo quiefur el arap con gajo ${ }^{131}$; fuerte como ajo él no ${ }^{132}$ se mostró. \\ Este caźic mos entró la Meśa Redonda ${ }^{133}$, ¡qué dolor profonda!}

${ }^{127}$ Nehama Dictionnaire s.v. arrés recoge la expresión «venir arres» que explica 'venir tout près du bord; être tout près d'épuiser toutes ses provision; être à la dernière extrémité', es decir, que los ha llevado hasta el límite de lo soportable; cfr. esp. a ras.

${ }^{128}$ NeHAMA Dictionnaire s.v. píno recoge la expresión «suvir a uno al pino» que traduce 'faire de quelqu'un un éloge outré', que aquí hay que entender como que les hizo concebir esperanzas.

${ }^{129}$ Nehama Dictionnaire s.v. pepíno recoge la expresión «salir pepino» para decir 'essuyer un échec, une grosse déconvenue là où l'on escomptait un succès'.

${ }^{130}$ Es decir, se ha puesto generoso, tolerante; cfr. tc. ferah.

${ }^{131}$ Nehama Dictionnaire s.v. gážo recoge la expresión «salir con gažo alto» equivalente a 'être prétentieux, arrogant, avoir des exigences inopinées [...]', es decir, poniéndose gallito.

${ }^{132}$ Según los posibles sujetos, el verso se puede entender de varias formas. Puede ser que los que no se mostraran fuertes fueran los británicos, que es lo más probable. Pero también cabe entender que esté aludiendo a los árabes (arap en sing.), en cuyo caso habría que poner tal negativa en relación con el artículo que se publica en la pág. 2 del mismo número del Mesajero que manejamos. Esto es lo que allí se dice en la cabecera: «La prensa ingleśa y el Libro Blanco. Revelaciones del Deili Telegraf.- Huseín el propio había agradecido la excluśión de la Palestina [de su integración en el Emirato de Transjordania, al que he aludido supra]»; y en el cuerpo del artículo se insiste diciendo que «[...] Huseín el propio no discutía que la Palestina era excluida del engajamiento de apoŷar la independencia áraḅa» y «[...] que el rey Huseín agradeció la excluśión y que la Palestina entraba en las espandiduras excluidas fueron no solo apoyadas por los gobernos ingleśes succesivos y por sir Henry Mac Mạ̣on, ma fueron aceetadas también por el rey Faisal del Irac, hijo del jerif Ḥuseín, y por el grande čhampión de la cavśa áraḅa colonel T. E. Lavrans [Thomas Edward Lawrence]». El asunto hace referencia a la correspondencia intercambiada en 1915-1916 entre McMahon y el entonces jerife de La Meca, Huseín ben Alí, para promover el levantamiento árabe contra los turcos en el transcurso de la Primera guerra mundial, a cambio del compromiso de los Aliados de promover un Estado árabe en la zona.

${ }^{133}$ Es decir, la Mesa Redonda nos ha traído este desastre (caźic). 
4 Vayiŝmán y n' Gurión ${ }^{134}$ mucho percuraron, por horas es un brullón lo que manobraron; ellos pelearon sin pueder vencer, no sabemos qué va ser. ¿De quién es el lloro?: yamim yedaḅeru ${ }^{135}$.

5 Dejemos en un quienar lo de Palestina, nada vamos a ganar con estar ansina ${ }^{136}$; fuerte es la quina, no hay d'espantar ${ }^{137}$ :

la luź puede espuntar, sin saber qué modo puede trocar todo.

6 Hoy fiestamos el Purim con paz y con goźo por lo que los yehudim stamos en repośo; vivimos hermośo en muestra civdad que gracias a la buendad de muestro goberno que mos mira bueno.

\section{La avaricia de los ricos de 1939}

El texto que publico procede de la siguiente fuente única:

- Versión aljamiada publicada en el periódico de Salónica Mesajero 4/1069 ([5 mar. 1939]) pág. 3 [?] ${ }^{138}$ col. dch.- Cabecera general: «Muestras complas de Purim »; cabecera propia: «Se acodren de los hijicos» ${ }^{139}$ [no en Baecs].

Copla inédita y anónima, que sigue a la editada en número precedente (núm. 10). Consta de 6 cuartetas zejelescas con vuelta de rima variable. Recordemos

${ }^{134}$ Es decir Hayim Weizmann (Motol, Bielorrusia 1874 - Rehovot, Israel, 1952), de quien ya me he ocupado arriba, y David Ben Gurión (Plonsk, Polonia 1886 - Sedé Boker, Israel, 1973), primer ministro de Israel entre 1948-1954 y 1955-1963, quien desde 1935 era presidente de la Agencia Judía.

${ }^{135}$ Nehama Dictionnaire s.v yamín yedaberu recoge la expresión que traduce 'laisons faire le temps', es decir, el tiempo dirá, frase que resulta premonitoria a la vista de lo que había de suceder casi diez años después; hb. מים ידברו yamim yedaberú (lit. 'los días hablarán'; en la aljamía la última palabra escrita ליידאברו לדיר).

${ }^{136}$ Escrito ansila.

${ }^{137}$ Es decir, por muy grave que sea la desgracia (hb. קינה quiná; que acentúo quina por mor de la rima), no hay que asustarse.

${ }^{138}$ Vid. nota 120 supra.

139 Íncipit de la popular copla de Sa adi Haleví El daledale dePurim (Baecs núms. 79b y ss.). 
que el modelo que se copia, es decir, la copla dicha de Sa'adi Haleví, consta de 9 cuartetas zejelescas con vuelta en $-l e^{140}$.

Esto es lo que nos dice, en crítica a los ricos del momento. Los ricachos, avaros y falsos filántropos, no se ocupan de los pobres padres de familia que tienen hijos a los que no pueden alimentar (estrs. 1-2), rehuyendo a las comisiones de beneficencia que vienen a pedirles su colaboración (estr. 3); si dan algo, o lo hacen de mala gana o por llamar la atención y presumir de su acción (estr. 4). Son juguetes de los caprichos y lujos de sus mujeres, y solo se ocupan del juego (estr. 5), importándoles un bledo que los pobres se mueran de hambre (estr. 6).

Obviamente en el trasfondo histórico está la misma crisis económica que hemos visto en textos anteriores y que afecta principalmente a los más pobres.

He aquí el texto.

1 No se acodran los ricos, los que les core choricos ${ }^{141}$, de los probes con chicos que sufren me amarim ${ }^{142}$.

2 Hay los guebirim ${ }^{143}$ escarsos que son filántropos falsos, miśmo que ven los estrazos no meten manos al gep.

3 Con empuǰos y presiones, con guayas o maldiciones, cuando salen comisiones se fuyen de el charší.

4 Los que dan, non dan con alma, $\mathrm{y}$, si dan, es por reclama; temblan como una rama cuando abren el borón.

${ }^{140}$ Vid. Iacob M. HAssán, «La tradición editorial de Salónica en las coplas de Purim», en Rena Molno (ed.), Judeo Espagnol: Social and Cultural Life in Salonika Through Judeo-Spanish Texts (Salónica 2008) págs. 59-73: págs. 65-66, núm. 2.4.

${ }^{141}$ Es decir, chorros de dinero, los que nadan en la abundancia.

${ }^{142}$ Escrito מי אמארים (cfr. hb. מי המרים 'aguas amargas'); vid. también nota 168 infra.

${ }^{143}$ Escrito גיבריר (cfr. hb. גמברים 'ricos, notables'). 
5 A los lusos y afeites de sus mujer son ${ }^{144}$ juguetes; al jogo tienen las mientes, hey las gastan ${ }^{145} \sin$ pensar.

6 Miśmo los que son pimienta ${ }^{146}$ por sus quief gastan sin cuenta; el probe, si se reventa, ellos no le dan pendar.

\section{Los males de 1940}

El texto que publico procede de la siguiente fuente única:

- Versión aljamiada publicada en el periódico de Salónica Mesajero (14 veadar [adar II] 5700 [= 24 marzo 1940, Purim]) pág. 5 (parte derecha) ${ }^{147}$.Cabecera general: «Complas de Purim y unos cuantos purimlic [...]. Compośamos las complas del felec que es muestro mejor purimlic para muestros lectores $[. .]$.$» ; cabecera propia: «Aźkir ḥasdé» { }^{148}$.

Poema inédito y anónimo, formado por 5 quintillas de rima aaaxy de versos con tendencia octosilábica y de pie quebrado el cuarto verso.

${ }^{144}$ Dice con.

${ }^{145}$ Lo que gastan son las monedas.

${ }^{146}$ Que no sé si quiere decir los que son más generosos o los que son más ricos.

${ }^{147}$ La copla me ha llegado en unas fotocopias incompletas en las que del nombre del periódico sólo puedo leer la $M$ de Mesajero y que he podido identificar gracias a que en una de las páginas que tengo delante aparece una de las entregas de las conversaciones entre «Tío Bohor y su mujer Jamila», estudiadas por David M. BunIs en su Voices from Jewish Salonika: Selections from the Judezmo Satirical Series Tio Ezrá I Su Mujer Benuta and Tio Bohor I Su Mujer Djamila by Moshé Cazés (Jerusalem - Thessaloniki 1999). Por desgracia Bunis no tiene en cuenta en su libro la entrega en la que aparece la copla que aquí aduzco, lo que me hubiera permitido saber de qué número se trata. La fecha que indico es la que figura en e-mail de 17 de sept. de 2003 dirigido a I. M. Hassán.

${ }^{148}$ Popular y muy difundido piyut hebreo de Abraham Ḥayún; la formulación completa del primer verso es «Aźkir hạsdé El neemán» ('Recordaré las clemencias del Dios fidedigno') y a él se adapta le copla sefardí que titulamos El Dio neemán (cfr. Baecs núms. 91d y ss.); vid. al respecto Iacob M. Hassán, Las coplas de Purim (Madrid: Hebraica Ediciones, 2010), pág. 238 nota 15 y 340-341 (copla VII) y sus artículos «Una nueva copla sefardí antigua del ciclo de la reina Ester (Purim)», Sefarad 67 (2007) págs. 416-435: pág. 420, núm. 15, y «Tradición editorial» págs. 59-73: pág. 70 núm. 13. Vid. también mi comentario sobre este texto en mi libro Yantares Introducción aprt. 2. 
Esto es lo que nos dice. El invierno ha sido muy crudo, con tormentas y heladas, provocando la muerte de muchos ancianos y obligando a las chicas jóvenes a salir con chanclos a la calle (estrs. 1-2), lo que no les ha quitado la risa de la boca (estr. 3). Y ya que se habla de mujeres, se aprovecha para afear el comportamiento de muchas alocadas (estr. 4), de lo cual tienen la culpa sus progenitores, que no las vigilan lo suficiente (estr. 5).

El texto es un ejemplo más de la historia de la sociedad de los Balcanes y de su evolución, y de él me interesa poner de relieve cómo, a pesar de que la emancipación de la mujer sefardí ya se había producido muchos años antes y también su incorporación a la vida laboral ${ }^{149}$, en fechas tan tardías como 1940 aún hay quienes critican, como es el caso, las risas de las mujeres y su presencia en los trasportes públicos, maquilladas y con el pelo rizado, así como la falta de vigilancia de los padres que no se dan cuenta de cómo se arreglan cuando salen a trabajar.

Veamos el texto.

1 Fuerte fue la enviernada, fortunośa y yelada, de las gripes y puntada a los viejos y a muchos alimpió ${ }^{150}$.

2 Hubo nieves, hubo quiinas ${ }^{151}$, voćes y reśbalatinas, safañones, comicinas, y las niñas con šosones y čhismés.

3 Con las nieves y las luvias y con tadradas trubias, gritaronas y marmullas y riendo al tram y al otoḅús.

${ }^{149}$ Vid al respecto mis artículos «Textos poéticos sobre la emancipación de la mujer sefardí en el mundo de los Balcanes», Sefarad 69 (2009) págs. 173-227, y 69/2 (jul.-dic. 2009) págs. 427-476; y «La emancipación de la mujer sefardí a través de textos poéticos», en Yolanda Moreno Koch - Ricardo IzQuIERdo Benito (coords.), Hijas de Israel, mujeres de Sefarad: de las aljamas de Sefarad al drama del exilio (Cuenca 2010) págs. 303-362.

${ }^{150}$ Frase irónica para decir que se los llevó por delante, que se murieron.

${ }^{151}$ Escrito קיינאס, probablemente hb. קינה 'elegía, endecha', que Nehama Dictionnaire s.v. kyína traduce también como 'mala suerte, desgracia, catástrofe'. 
4 Muchas hay descomportadas, andoladas y pintadas, locas que quieren atadas ${ }^{152}$, que mos piedren la valor y la honor.

5 Es la culpa de las madres y descuido de los padres: que las mañanas y tadres las survellen cuando se van al labor.

\section{La avaricia de los ricos de 1940}

El texto que publico procede de la siguiente fuente única:

- Versión aljamiada publicada en el periódico de Salónica Mesajero (14 veadar [adar II] 5700 [= 24 marzo 1940, Purim]) pág. 5 (parte derecha).- Cabecera general como en el núm. 12 supra; cabecera propia: «Se acodren de los hijicos» ${ }^{153}$ [no en Baecs].

Copla anónima e inédita que pertenece al mismo lote del que publico en número precedente (núm. 12). Está compuesto por 6 cuartetas de rima zejelesca y versos de tendencia octosilábica, quedando suelto el verso de vuelta.

Esto es lo que dice. Los ricos son en su mayoría avaros (estr. 1) y no ayudan ni a sus parientes (estr. 2), mirando para otro lado ante los problemas de los pobres (estr. 3). Sin embargo, a muchos no les sirve de nada su riqueza: si bien no tienen preocupaciones ni problemas económicos, miles de enfermedades los acosan o les impiden disfrutar de sus haciendas; sus amantes les sacan el dinero a mansalva; están todo el tiempo a expensas de los médicos y sin darse un descanso en su afán por ganar más dinero (estrs. 4-6).

Cabe señalar que en dos años consecutivos el Mesajero recurre como modelo a la misma copla Daledale de Sa 'adi Haleví y con el mismo objetivo: fustigar a los ricos.

Veamos el texto.

1 No se acodran los ricos que tienen buenos hechicos;

${ }^{152}$ Es decir, que deberían ser atadas.

${ }^{153}$ Sobre el ejemplar que manejo vid. nota 147 supra, y sobre el íncipit melódico vid. nota 139 supra. 
ganan de muchos choricos, viven con escarcedad.

2 Son de corazón livianos, sidean gepes y manos ${ }^{154}$, ni a primos ni a hermanos percuran de ayudar.

3 Yiven en jemanfutistas, no suscriben en las listas ${ }^{155}$, no dan, son tapón de vistas ${ }^{156}$ para el pan de el probe.

4 Hay ricos sin criaturas, sin gailet, sin secaturas, unflados de hacinuras, de ellos no hay haír ${ }^{157}$.

5 Hay quien tiene a montañas con mujeres piripañas ${ }^{158}$ que se quitan las pestañas sin gozar de sus pará.

6 Con doctor todo el tiempo, al alma tienen un cepo; no consolan a sus puerpo muertos detrás del pendar.

${ }^{154}$ Quizá haya que poner sidean en relación con tc. sed çek- 'poner barreras' para decir que cierran bolsillos ( gepes) y manos y no sueltan un duro.

${ }^{155}$ Es decir, no suscriben las listas que las organizaciones de beneficencia organizan para ayudar a los pobres.

${ }^{156}$ NeHAma Dictionnaire s.v. tapón recoge la expresión «tapon de vista» que explica 'personne très laide, objet déplaisant, dont la vue est désagréable', si bien aquí podría significar que se tapan los ojos para no ver los problemas de los pobres.

${ }^{157}$ Es decir, aunque no tienen ninguno de los problemas que se señalan en los dos primeros versos, sin embargo sufren de múltiples enfermedades. NeHAma Dictionnaire s.v. jayír recoge la expresión «no ay jayir», que traduce 'il n'y a aucun profit à tirer'; cfr. tc. hayır, hayr 'provecho, ventaja', o lo que es lo mismo, de esos ricos es mejor olvidarse, porque no sirven de nada.

${ }^{158}$ No he conseguido averiguar qué tipo de mujeres son esas, ni si hay que poner la palabra en relación con tc. peri 'hermoso', tc. pirî 'anciano' o con otra palabra que no he sabido precisar; obviamente tampoco sé si he trascrito bien lo escrito פיריפאניאס. 


\section{Tinieblas del Holocausto}

El texto que publico procede de la siguiente fuente única:

- Versión aljamiada publicada en el librito Libertad querida, de Alexandro Pérez̧ (Tel Aviv, 21 iyar 709 / 20 mayo 1949) págs. 11-12.- Cabecera: «Tinieblas... (Después de la deportación y de la fin tráǵica de mi mujer y de mi hijo)» ${ }^{159}$.

Poema de Alexandro Pérez̧, formado por 6 cuartetos de rima $A B A B$. El texto en letra cuadrada. Al pie del texto: «Niza (Francia), el 30 abril 1945».

No puedo negar mi especial afecto por este autor, del que he editado un total de doce poemas ${ }^{160}$, en su mayoría coplas en nonetas octo-hexasílabas, que rezuman humor e ironía criticando los acontecimientos de su actualidad. Sin embargo, apenas tengo datos de su vida, aparte de los que sobre él nos comunica Gaon ${ }^{161}$, sobre su colaboración en tres periódicos humorísticos de Salónica: hacia 1914 era responsable de El Martío; hacia 1920 era redactor de El Chaquetón; y más o menos en 1922 lo era de El Čharló.

En la Introducción de mi libro Entre dos afirmaba (págs. 23-24) ${ }^{162}$ que no iba a ocuparme de la poesía sefardí sobre el Holocausto y por tanto no incluí allí este poema. Pero, dado mi declarado aprecio por Alexandro Pérez, me parece llegado el momento de sacar del olvido este poema, donde nos refleja sus per-

${ }^{159}$ Otro de los poemas del librito lo he editado en Entre dos cap. 19, núm. 174 (págs. 765766), bajo el título de Las vejaciones de antaño.

${ }^{160}$ El titulado Los nuevos ricos ya apareció en mi libro Coplas sefardíes: Primera selección, Intr. Iacob M. Hassán (Córdoba 1988) núm. 17 (págs. 135-139). Cinco de ellos los he publicado en mi libro Entre dos: núms. 101 (Las guerras del rey Fernando), 129 (Tiempos de crisis), 130 (El Purim de antaño I), 131 (Tiempos de carestía), 132 (Las promesas de los gobernantes), 156 (El emigrante ambicioso) y el ya aludido en nota anterior núm. 174 Las vejaciones de antaño. Algunos de ellos y por estar en nonetas octo-hexasílabas los reedité en mi libro $Y$ hubo luz: núms. 27 (Los nuevos ricos), 29 (El Purim de antaño I), 30 (Tiempos de crisis), 31 (Tiempos de carestía), y 32 (Las promesas de los gobernantes), a los que añadía otros dos: núms. 36 (El Purim sin dinero), y 37 (El Purim de antaño II). Vid. también mis artículos «Textos poéticos sobre la emancipación de la mujer» núms. 8 (Pasión por las modas) y 17 (El gancho), y «Las coplas novísimas de Purim: temas y tópicos», en Yvette BürKI - Elena RoMERo (eds.), La lengua sefardí: Aspectos lingüísticos y literarios (en prensa), en donde reedito El Purim sin dinero y El Purim de antaño II.

${ }^{161}$ Moshe David Gaon, A Bibliography of the Judeo-Spanish (Ladino) Press [en hebreo] (Tel Aviv 1965) núms. 279, 165 y 81, respectivamente.

${ }^{162}$ A la bibliografía allí citada en nota 9 añádase ahora el libro de Shmuel ReFAEL, Un grito en el silencio: La poesía sobre el Holocausto en lengua sefardí, estudio y antología (Barcelona 2008) y la bibliografía por él mencionada. 
sonales sufrimientos por la desgracia acaecida a su familia -su mujer y su hijo habían muerto en los campos de concentración nazi- y nos muestra un estado de ánimo bien distinto del jocundo que mostraba en sus poemas y coplas anteriores al Holocausto.

La cabecera del texto nos informa de que su familia fue deportada, y ello tuvo que ser en algún momento a partir del invierno de 1943, fecha en que los nazis iniciaron en Grecia sus deportaciones de judíos a Polonia, a los campos de Auschwitz-Birkenau; pero tengo mis dudas sobre si él también fue deportado o había conseguido huir de Salónica, dejando atrás mujer e hijo en la idea de que los alemanes solo actuarían sobre los hombres. Explicaré en que estriban mis dudas.

Por la citada frase que remata el poema que edito - «Niza (Francia), el 30 abril 1945»-y por lo que luego diré, sabemos que nuestro autor sobrevivió al Holocausto. Si, como he dicho arriba, hacia 1914 Pérez̧ era redactor de El Čharló, podemos suponer que por entonces estaría entrado por lo menos en la veintena -digamos 23 años-; ello quiere decir que en 1943 andaría por la cincuentena. Y recordemos lo que al respecto nos dice, por ejemplo, Itshac Cohen ${ }^{163}$ : que en Auschwitz, a todos los judíos mayores de 45 años y menores de 15 los llevaba a las cámaras de gas el mismo día de su llegada al campo. Así pues, las preguntas que surgen son, de haber llegado Pérez̧ a Auschwitz, ¿habría podido librarse de la quema inmediata?; y de haberlo logrado, ¿podría un hombre de su edad haber sobrevivido dos años a los horrores de la vida en los campos?; cuando el 27 de enero de 1945 los soviéticos liberaron el campo, ¿se encontraba allí Pérez̧?; y si no estaba allí por haber sido trasladado con anterioridad, ¿fue capaz de arrostrar y sobrevivir a la correspondiente «marcha de la muerte» en la que los alemanes arrastraban a los presos hacia otros campos en Alemania en un intento de borrar las huellas de sus crímenes, siendo después liberado en algún otro campo, como Bergen-Belsen, que lo fue el 15 de abril de 1945, o Buchenwald, liberado el 11 de abril de ese mismo año?

En los títulos de los capítulos de su diario Cohen hace referencia a su forzada salida de Auschwitz y el viaje a Buchenwald (núms. 55-56), su liberación el 11 de abril de 1945 (núm. 61), el traslado a París en aviones americanos (núm. 68), el viaje a Marsella, donde los refugiados fueron albergados en un campo

${ }^{163}$ En «Salonique - Auchwitz - Yeruchalaim», en David A. Recanati (redactor), Zikhron Saloniki ..., 2 vols. (Tel-Aviv 1972 y 1986) vol. II, págs. 41-42 (resumen en judeoespañol): pág. 41, y 577-599 (texto hebreo): págs. 587 y 588; vid. en págs. 592-593 los títulos de los capítulos de su diario a los que aludo luego. 
americano (núm. 72), y el traslado a Bari a un campamento inglés desde donde embarcó para Atenas (núm. 74). De haber sido Pérez̧ también uno de los liberados, ¿pudo seguir una ruta semejante, al menos hasta llegar a Marsella?, ¿tenían los trasladados libertad de movimientos como para que nuestro autor pudiera irse a Niza?

Ante tanta duda, recurrí a quien sabe mucho más que yo de estas cosas, mi querido amigo Shmuel Refael (Universidad de Bar Ilan). Él y mi también muy querida amiga Susy Gruss se pusieron en movimiento e hicieron toda suerte de averiguaciones en los libros publicados sobre el Holocausto en Grecia y en las listas difundidas por Yad Vashem, sin encontrar rastro de nuestro autor. También me confirma Refael que la edad media de los sobrevivientes de los campos no superaba la treintena y que el mayor de todos ellos, Mošé Šemuel de Salónica tenía unos 40 años, por lo que recibió el apodo cariñoso de «el nono» ('el abuelo').

Aunque probablemente mis preguntas anteriores no tendrán nunca una respuesta concreta, me inclino a aceptar como buena una de las posibilidades que he propuesto más arriba: que Pérez̧ no llegó a ser deportado y que de alguna manera salió de Grecia camino de Francia, bien antes de que se iniciaran las deportaciones, bien tras pasar un tiempo entre los partisanos griegos o refugiado en las montañas. En cualquier caso, lo que sí sabemos de su vida posterior es lo ya dicho: que a finales de abril de 1945 Pérez̧ estaba en Niza; y que, como veremos después (núms. 15-19), para 1949 ya había emigrado a Israel, donde lo encontramos establecido en Tel Aviv.

Esto es lo que nos dice el poema. En sus pesadillas el autor recibe las apariciones de un hombre, que supone ser por un habitante del Paraíso, al que ruega que le haga ver a su familia (estrs. 1-2). La aparición le ha transmitido otras dos visiones: un padre llorando ante la tumba de su hijo (estr. 3); y un joven que se lamenta ante la de su amada (estr. 4). Con ironía, afirma el autor que, aunque ello sea un flaco consuelo, al menos tales personas pueden acudir a visitar a sus muertos, no como él que los sabe consumidos por las llamas (estr. 5). Aunque respeta la decisión de los cielos, ruega a su visitante en sueños que le diga si los suyos están en los cielos (estr. 6).

Veamos ya el texto; en mi edición respeto los puntos suspensivos del original.

1 Non sé quién sos tú, que vienes en mis sueños, y me mostras čenas llenas de espanto; non entiendo ni tus gestos ni tus siños, ma tu forma me diće que sos un santo. 
2 Si tú sos un santo, un esprito puro, yiviendo allí, adentro los untados ${ }^{164}$, quita de mis ojos el velo escuro..., haź a que me soñe con mis dos quemados.

3 La otra noche me mostrates un hombre verter lágrimas sobre la sepultura de un difunto que llevaba su nombre: era la morada... de su criatura.

4 Más allí, pośando un mazo de flores, un mancebo se roja sobre la tumba de la que le tuvo dado sus amores llamándola: «Mi treśoro, mi palomba».

5 Liviana consolación, ma consolación: ellos saben ónde llorar sus queridos; non ỵiven, como mí, en la deśolación de saberlos por las flamas consumidos...

6 Ven en mis sueños, malgrado tu calladez, yo respectaré lo que el cielo hiźo..., esperando que me dirás alguna vez si ellos se topan en el Paradiśo.

\section{La independencia de Israel}

El texto que publico procede de la siguiente fuente única:

- Versión aljamiada publicada en el mismo librito citado en núm. 14 (Tel Aviv, 21 iyar 709 / 20 mayo 1949) págs. 1-7.- Cubierta y cabecera (pág. 1): «Libertad querida, Primos versos de Alexandro Pérez̧ en Yisrael, compośados a la ocaśión del primo aniversario de la independencia judía» [Baecs núm. 263a].

Copla de Alexandro Pérez̧, formada por 12 nonetas octo-hexasílabas. El texto en letra cuadrada y las estrofas separadas por una rayita centrada.

En la Introducción de mi libro Entre dos decía (pág. 23) que en él no me ocupaba de los poemas en relación «con la fundación y las vicisitudes del Estado de Israel» y entre los textos excluidos mencionaba esta copla de Alexandro Pérez̧ (nota 8 pág. 24). Sin embargo, he decidido ahora rescatarla del olvido, fundamentalmente por su categoría de copla de «como en Purim», tipo del que ya me

${ }^{164}$ Se refiere a las almas que habitan en el Paraíso. 
he ocupado anteriormente ${ }^{165}$. Cabe comentar que del subtítulo del librito $-\ll$ Primos versos de Alexandro Pérez̧ en Yisrael»-, que no deja de resultar ambiguo, podría desprenderse que nuestro autor había llegado no mucho antes a Israel.

Esto es lo que nos cuenta. Con la independencia del Estado de Israel se han acabado las penas de los judíos (estr. 1), independencia que se han ganado a pulso los soldados que han luchado en la así llamada Guerra de Liberación y también Guerra de la Independencia (estr. 2), quienes se lanzaron al ataque enardecidos, rezando la oración de la Šemá، (estr. 3) y cuyo valor ha causado el asombro de todas las naciones (estr. 4); como los antiguos Asmoneos, han sabido defender la tierra de sus antepasados (estr. 5). Los judíos ya se temían el ataque y el cerco de los estados árabes circundantes, que no pudieron con ellos (estr. 6), abandonando en su huida armas y bagajes (estr. 7). Las mujeres han luchado con el mismo valor que los hombres (estr. 8) y la guerra se ha ganado gracias a la Haganá, que se ha comido a los árabes -a pesar de haber recibido estos ayuda del exterior- como quien se come un plato de albóndigas con arroz (estrs. 9-10). Por desgracia, la guerra se ha cobrado la vida de muchos jóvenes, que han dejado a sus madres desoladas (estr. 11), acabando el poema con la exhortación a trabajar duramente por la reconstrucción del país y a estar siempre alerta para defenderlo.

Recordemos brevemente el trasfondo histórico, haciendo hincapié en los datos que se mencionan en el texto ${ }^{166}$. El 20 de noviembre de 1947 las Naciones Unidas acordaron la tan traída y llevada partición de Palestina en dos estados, asunto que ya he comentado en núm. 10 supra, y se fijó el fin del Mandato Británico en la zona para el 15 de mayo de 1948. Tal partición fue ahora acepada por los judíos, pero no por los árabes.

Los meses que transcurrieron hasta la salida de los ingleses fueron de constantes disturbios, que pasaron a ser guerra abierta cuando el 14 de mayo de 1948 Ben Gurión proclamó la independencia de Israel. «El mismo día de la retirada británica de la región, tropas libanesas, sirias, iraquíes, egipcias y transjordanas, apoyadas por voluntarios libios, saudíes y yemeníes, comenzaron la invasión del recién proclamado Estado judío» ${ }^{167}$. Había comenzado la guerra en la que Israel se vio forzada a defender la soberanía recién recobrada en su patria ancestral. La guerra, que concluyó con una rotunda victoria por parte de Israel, había de durar hasta los distintos armisticios firmados en la primera mitad de 1949 entre Israel y los diferentes estados árabes combatientes.

${ }^{165}$ En mi artículo «Coplas novísimas», así como en mi libro Y hubo luz.

${ }^{166}$ Extraigo algunos datos de la Wikipedia (http://es.wikipedia.org: guerra árabe-israelí de 1948, consultada el 19 sep. 2010).

${ }^{167}$ Vid. nota anterior. 
Según los datos de la Wikipedia (loc. cit.) las varias fuerzas paramilitares de Israel -que quedaron unificadas en mayo de 1948- contaban en un principio con unos 35.000 soldados, en su mayoría pertenecientes a la Haganá, en alguna de cuyas secciones había mujeres integradas (a las que se alude en estr. 8); el número llegó a incrementarse a 115.000 en la última fase de la guerra. Por parte árabe estas son más o menos las cifras en las distintas fases del conflicto: las fuerzas paramilitares palestinas contaban con unos 12.000 voluntarios, a los que hay que sumar los cerca de 6.000 combatientes integrados en el llamado Santo Ejército de Liberación; la Legión Árabe Jordana, formada por 11.000 soldados que habían sido entrenados y dirigidos por oficiales británicos; los 18.000 hombres del ejército de Irac; los soldados egipcios que llegaron a ser cerca de 20.000; unos 12.000 soldados sirios y 3.500 libaneses; más los cerca de 1.200 soldados enviados por Arabia Saudí y un grupo indeterminado que llegaron de El Yemen. Todo ello arroja una cifra de unos 84.000 soldados (los «millones» mencionados en estr. 5). Las bajas del ejército israelí (aludidas en estr. 11) ascendieron a 6.373 muertos, lo que representaba el $1 \%$ de la población.

Veamos el texto.

1 Cantaremos, haberim, la fin de las penas, no hay más meamarim ${ }^{168}$, no hay más cadenas;

en tierras ajenas cualunque jiidió

debe rengraciar su Dio

porque es contado y considerado.

2 Como todos, Yisrael merece respecto; en el fronte mostró él su arte parfecto: se mostró correcto, del todo ${ }^{169}$ brutal,

y su ex́empio fue tal que es apreciado como buen soldado.

3 Canso de tanto sufrir, el pueblo erante dijo: «Por pueder yivir, hermanos, avante; la Šemá ${ }^{170}$ con cante, sin mirar atrás, y ansí non puedrán más los civiliźados... ${ }^{171}$ matar deśarmados».

168 Escrito מיאמארים; cfr. nota 142 supra.

${ }^{169}$ Es decir, en absoluto, de ninguna manera; cfr. fr. du tout 'de ningún modo'.

${ }^{170}$ Escrito שמה (hb. שמע Sמemá' 'Escucha'), íncipit de la oración formada por los pasajes bíblicos de Deut 6:4-9, 11:13-21 y Núm 15:37-41, que constituyen la profesión de fe del judaísmo y es la oración principal de la liturgia sinagogal. También se usa como responsorio fúnebre y este es el sentido que aquí tiene, es decir: se lanzaron a la batalla preparados para morir.

${ }^{171}$ Frase irónica que no sé con seguridad a quién la dedica el autor, pero no me extrañaría nada que estuviera pensando en los ingleses. 
4 Yisrael apercantó todos los estados, el mundo se encantó al ver sus soldados: hijos regalados ${ }^{172}$ preferar muerir más presto que de yivir siempre humillados y menospreciados.

5 Como los Hašmonim ${ }^{173}$, raza de leones, sus hermanos yehudim entre los canones contra los millones pudo combatir, supo su sangre vertir ${ }^{174}$ bajo estos cielos de muestros agüelos.

6 Yisrael se defendió, él fue atacado; del primer punto sintió estar menaźado y miśmo blocado por los felahim, ma él les dio derahim ${ }^{175}$ con sus bayonetas sin sonar trompetas ${ }^{176}$.

7 Mos quierían englutir dos en un bocado, les vino grande batir al ver el fonsado del pueblo harbado, del pueblo martir; mos dejaron por hatir ${ }^{177}$ tanques de los jones ${ }^{178}$..., armas con vagones.

8 Y las hijáas de Ŝiyón merecen homaǵe, merecen admiración, porque con coraǵe, como hombres cas̀e, supieron tener

${ }^{172}$ Aquí con el sentido de jóvenes acostumbrados a una vida regalada.

${ }^{173}$ Se refiere a los Asmoneos, herederos de la familia de los Macabeos (175-165 a.E.c), que encabezaron la revuelta contra los griegos seleúcidas Antíoco IV Epifanes y su hijo Antíoco V Eupator, a los que consiguieron expulsar de Tierra Santa, con la consiguiente purificación del Templo, profanado por los griegos, lo que en el mundo judío se celebra en la fiesta de Ḩanuká.

${ }^{174}$ Vocalizo así por mor de la rima.

${ }^{175}$ Escrito דרהים, deformación de hb. דרכים derajim lit. 'caminos'; Nehama Dictionnaire s.v. derajím explica la palabra como interjección 'fuyezi, quittez ces lieux!', así pues hay que entender dar derahim como 'obligarlos a marcharse, expulsarlos'.

${ }^{176}$ Parece aludir a las trompetas de las que Josué se sirvió para derrocar las murallas de Jericó, que aquí no han hecho falta.

${ }^{177}$ Expresión irónica que Nehama Dictionnaire s.v. jatír recoge diciendo 'par pure condescendance' (tc. hatır 'consideración, respeto'); acentúo martir en el verso anterior y no mártir por mor de la rima.

${ }^{178}$ Escrito גוניס; es decir, de «los Johnes», de los ingleses; vid. NeHAma Dictionnaire s.v. Ğon. 


\author{
sus misión y sus dober \\ por sus país santo sin ningún espanto. \\ 9 Esta guerra fue toaf como albondigas, \\ las armadas del pilaf... o de las espigas... ${ }^{179}$ \\ fueron englutidas por la Aganá ${ }^{180}$, \\ gritando a Dio «maná» \\ barraganes falsos fuyeron descalzos. \\ 10 Malgrado que tal o tal... fueron ayudados ${ }^{181}$, \\ presto tomaron partal ${ }^{182}$, los deśmaźalados \\ fueron rempuǰados f[i]n al cabininé...; \\ si non era bilmem ne ${ }^{183} \ldots$, \\ iba ser pepino de Abraham abinu... ${ }^{184}$. \\ 11 La victoria mos costó miles de hermanos, \\ muchos cuerpos arrastó de mancebos sanos; \\ mos dimos las manos ${ }^{185}$ para consolar, \\ protejar y ayudar \\ las madres quedadas tanto deśgraciadas ${ }^{186}$.
} rima.

${ }^{179}$ No entiendo la alusión a las espigas; en el verso anterior acentúo albondigas por mor de la

${ }^{180}$ Escrito אגאנה, hb. הגנה Haganá, nombre de la más importante organización paramilitar de los judíos en tiempos previos a la formación del Estado.

${ }^{181}$ Los tales ayudados, según el autor, fueron los países árabes y la ayuda la prestó Inglaterra. Quizá podamos ver en ello una alusión a la participación en el conflicto de algunos aviones ingleses que actuaron sobre Israel en noviembre de 1948 y también en junio de 1949, cuando estaba a punto de firmarse el acuerdo de alto el fuego definitivo, y que provocaron la protesta de la oposición en el Parlamento británico acusando al gobierno de intervenir en la guerra en favor de los estados árabes (vid. Wikipedia loc. cit.).

${ }^{182}$ Cfr. tc. parsal 'harapo, andrajo'; NeHAma Dictionnaire s.v.partál traduce 'paquet de vêtements, de linge mal lié, baluchon', es decir, que se echaron el hatillo al hombro para marcharse.

${ }^{183}$ Escrito בילמים ני, que no sé si hay que poner en relación con tc. bilmece 'de broma', y que, por supuesto, no sé si he vocalizado correctamente.

${ }^{184}$ Como ya he dicho antes (nota 129) NeHAma Dictionnaire s.v. pepíno recoge la expresión «salir pepino» que explica 'essuyer un èchec, une grosse déconvenue là où l'on escomptait un succés'; el no entender bien el verso anterior me impide afirmar que la ironía de Pérez̧ quiera decir que de no haber sido por lo que no he entendido hubiera sido todo un desastre para Abraham, como personificación de los judíos.

${ }^{185}$ Que tanto puede ser 'nos hemos esforzado' como 'nos hemos puesto de acuerdo'.

${ }^{186}$ Pérez̧ vuelve a insistir en el tema de los caídos en la guerra y en las doloridas madres en sendos poemas publicados en su Buqueto de poemas (vid. datos bibliográficos en núm. 17 infra): el titulado Himno a Israel (pág. 5) y el sin titular, que comienza «Madres aḅatidas» (pág. 6). 
12 Laboremos con ardor, con amor y ćelo por conservar la grandor bajo muestro cielo; porque ningún velo la pueda truḅlar, todos debemos velar, la frente en alto, prontos al asalto.

\section{Penurias en el Israel de 1949}

El texto que publico procede de la siguiente fuente única:

- Versión aljamiada publicada en el librito citado en núm. 14 (Tel Aviv 21 iyar 709 / 20 mayo 1949) pág. 8.- Cabecera (pág. 1): «Pan y agua y diñitá».

Poema de Alexandro Pérez̧, compuesto por 3 cuartetos de rima $A B A B$ con versos con tendencia dodecasílaba y visos de dos hemistiquios.

Esto es lo que nos cuenta. Siempre los principios son malos, pero hay que tener paciencia y confiar en el futuro del Estado de Israel (estr. 1); sin duda, con el tiempo mejorarán la alimentación y las viviendas (estr. 2); en cualquier caso, mejor es comer con frugalidad que ser considerados como seres inferiores (estr. 3).

Recordemos el trasfondo histórico. Ya desde los primeros meses tras la declaración de independencia de Israel y como respuesta a la llamada Ley del Retorno, según la cual se reconocía el derecho de todos los judíos del mundo a establecerse en el hogar ancestral, llegaron al flamante Estado unos 50.000 emigrantes, número que hacia finales de 1951 llegaría a ser de 687.000, hombres, mujeres y niños. Es obvio que el nuevo país vivió años de severos aprietos económicos para reconstruir un territorio arruinado por la guerra de independencia y que debía enfrentarse a la necesidad de mantener a una población en tan rápido crecimiento.

Veamos el texto.

1 Visto que todo empecijo es canseriośo, es con la pacencia que debemos esperar a que muestro sol sea más radiośo a fin que el país pueda prosperar.

2 Si muestros comeres non están de boda ${ }^{187}$, cale haćer pacencia y sin protestar; y si muestras caśas non son de la moda, esperemos con calmo un mejor bienestar.

${ }^{187}$ Es decir, no son tan sustanciosos como los esperados en una boda. 
3 Salado ${ }^{188}$, aćeitunas, queśo o margarina es mejor que gallinas; es el peje mejor de ciertos países ${ }^{189}$ de maldicha memoria... onde el jidió fue tratado de inferior.

\section{Penurias en el Israel de 1952}

El texto que publico procede de la siguiente fuente única:

- Versión latinada publicada en el librito de Alexandre Pérez, Buqueto de poemas y cantes [...] (Tel Aviv, 5712 - 1952; [al pie de la contracubierta y en hebreo:] Defús Rambam) pág. $3^{190}$.- Cabecera: «Nuestra chica meśa».

En letras latinas e impreso de izquierda a derecha. Para evitar discordancias con los otros textos aquí editados, transcribo según mi sistema, pero respeto la vocalización; son también mías la acentuación y puntuación, pero mantengo -cuando los hay- los puntos suspensivos de este texto y de los dos siguientes que tomo del mismo libro. Corrijo sin avisar los errores gráficos.

Poema de Alexandro Pérez̧, compuesto por 4 estrofas que son pareados emparejados de versos de 12 sílabas con tendencia a dividirse en dos hemistiquios.

Esto es lo que nos dice. Tres años después del poema anterior, si bien la fecha de edición de este de ahora no nos asegura que fuera escrito en 1952, el poeta insiste en los mismos problemas que allí nos ha descrito: la parquedad de alimentación en el Israel del momento ${ }^{191}$. El poeta se pregunta qué valor tienen las mesas opíparas si no son suyas (estr. 1); se conforma con lo que tiene, en donde, si bien falta la carne, hay pescados, yogurt, queso (estr. 2) y frutas, como mandarinas, naranjas y pomelos (estr. 3), concluyendo que es mejor comer sin mucha variedad a hacerlo con angustia (estr. 4).

${ }^{188}$ Es decir, pescado salado.

${ }^{189}$ Es decir, que vivir y comer en esos países que se mencionan a continuación.

${ }^{190}$ Uso fotocopia de la JNL S 2005 B 17; las páginas finales del librito, dedicadas a publicidad, van sin numerar (págs. [30-31]) y en ellas encontramos varios anuncios de empresas de Tel Aviv: el de la citada imprenta, ahora con el nombre escrito también en caracteres latinos -«Imprimería Rambam»-y el de la novela La hija maldicha que se estaba publicando en folletones en el periódico La Verdad (pág. [30]); el de un fabricante asquenasí de sombreros (Yaakov Moskovitch) y el de un carpintero sefardí (Zakay Benveniste) que ofrece «toda sorta de dogramá» (pág. [31]); y en la contracubierta y en consonancia con lo que se dice en v. $2 \mathrm{~d}$ del poema, figuran los hermanos «Chevah» fabricantes de yogurt y queso.

${ }^{191}$ Vuelve a insistir en el mismo tema en el poema (sin título) que sigue a este en el mismo libro pág. 4. 
Veamos el texto.

1 ¿Qué mos emportan estas meśas garnidas de ricas bibiendas, de buenas comidas?

Ninguna valor para mí ellas tienen, porque estas meśas no me apartienen.

2 La chica meśa que yo tengo, es mía, ¡yo como poco, ma con qué alegría!; si manca la carne, hay peǰe sin peśo ${ }^{192} \ldots$, por ajustamiento hay yogurt y queśo.

3 No hay mucha fruta, mas hay clementinas, hay las portocales que dan vitaminas..., hay las eškoliot que haćen provecho miśmo a aquellos que sufren de pecho.

4 Mi meśa es chica, ma hago loores y yo no la troco por las más mijores, porque estas meśas, ricas en sustancia, si hinchen la tripa, la hinchen con ansia.

\section{Los males del invierno}

El texto que publico procede de la siguiente fuente única:

- Versión latinada publicada en el librito citado en núm. 17 (Tel Aviv, 5712 1952) pág. 7.- Cabecera: «Invierno...».- Al pie del texto la firma «Sando».

Poema de Alexandro Pérez̧, compuesto por 4 estrofas de rima $A B B A$, algunos de cuyos versos, de tendencia dodecasílaba, pueden partirse en dos hemistiquios.

Esto es lo que cuenta, sin que pueda afirmar que el texto aluda a un hecho sucedido en Israel, ya que me parece algo dudoso para esas tierras el intenso frío que se describe. Como alternativa se me ocurre que nuestro autor se este refiriendo al intenso frío que sufrieron los judíos salonicenses, cuando, tras el incendio de Salónica de 1917, pasaron un largo tiempo viviendo muchos de ellos en tiendas de campaña y soportando los rigores de un crudísimo invierno. De todo ello me he ocupado en Entre dos (cap. 14, esp. pág. 657).

El invierno ha dejado el campo muerto (estr. 1) y un hombre enfermizo (quizá el propio autor) se pregunta angustiado si podrá resistir hasta la primavera

${ }^{192}$ Es decir, en abundancia. 
(estr. 2). Los pobres se preocupan por sus hijos sin recibir la ayuda de los pudientes (estr. 3), y también padecen el frío los que viven en tiendas de campaña, exigiendo el autor que los ricos se ocupen de ellos (estr. 4).

Veamos el texto.

1 Por el frío el campo está dormido, flacas son las plantas, probes los sembrados, deśnudas las viñas, sin flores los prados, el páj̆aro fuye, dejando su nido.

2 El hombre enfirmo con espanto siente el viento yelado harbar ${ }^{193}$ a su puerta...; ¿verá él de nuevo frutos en la güerta o va despartirse de entre la ĝente ${ }^{194}$ ?

3 El probe suspira en viendo sus chicos que mancan de colchas y mantinimiento. Hay, portanto, tantos que ni un momento pensaron a ellos, cuantunque son ricos.

4 Hay bajo las tiendas muchos aḅatidos que sienten la noche ${ }^{195}$ la rabia del frío. Aqueos que tienen y caśa y brío ${ }^{196}$ que den de sus paños a los mal vistidos.

\section{Los males de 1952: la Guerra Fría y la Guerra de Corea}

El texto que publico procede de la siguiente fuente única:

- Versión latinada publicada en el librito citado en núm. 17 (Tel Aviv, 5712 - 1952) págs. 9-12.- Cabecera: «Las nuevas complas adaptadas al estado de cośas en el mundo (se pueden cantar al son de las complas de Purim: "Cuando Amán se emborachó"

${ }^{193}$ En el original latinado escrito harbar.

${ }^{194}$ Es decir, o va a morirse.

${ }^{195}$ Es decir, por la noche.

${ }^{196}$ Que no sé si es como español brío, enfrentado al débil de v. 2a, o brillo como sinónimo de riqueza.

${ }^{197}$ Se trata del v. 11a de la copla titulada La caída de Amán cuya edición más antigua que conozco vio la luz en Salónica en 1798 (vid. Baecs núms. 34 y ss.). De la perduración de esta estrofa en la tradición oral, contaminando otras diversas coplas de Purim, me ocupo en mi libro Yantares cap. $1^{\circ}$ VII.12, y cap. $2^{\circ}$ I.6 y I.9, y IV passim. 
Copla de Alexandro Pérez̧, compuesta por 7 nonetas octo-hexasílabas.

Esto es lo que nos cuenta. Tras mostrar los males actuales y expresar una vez más la idea del ubi est Purim ${ }^{198}$ (estr. 1), acusa a las potencia occidentales de su hipocresía, señalando además el error cometido por Inglaterra al haber vendido armas a los árabes (estr. 2). De sus acusaciones no se libran los Estados Unidos, al tiempo que, con visión profética, pone de relieve la amenaza que la China comunista supone para el mundo (estr. 3): los chinos, pese a su pobreza, no paran de engendrar hijos, e incluso los que no tienen muchas luces no carecen de medios de manutención y no les amedrenta ni la amenaza de la bomba atómica ni de otros males semejantes (estr. 4). Alude a la guerra de Corea, expresando el autor sus temores de que tal conflicto se generalice (estr. 5). Solo Dios puede salvar al mundo de su destrucción (estr. 6) y Pérez̧ exhorta a todos los hombres de fe y en especial a los judíos a implorar su ayuda para que las generaciones futuras gocen de paz, ansiando que se acaben las tensiones de la llamada Guerra Fría que ha arruinado a las gentes (estr. 7).

Precisemos brevemente el trasfondo histórico. La guerra entre las dos Coreas, la del norte y la del sur (estr. 5), cuyos límites se habían fijado tras la Segunda guerra mundial en el paralelo 38, estalló el 25 de junio de 1950 y finalizó el 17 de julio de 1953 poco después de la muerte de Stalin. Ya que la copla se publicó en 1952, ello quiere decir que nuestro autor escribe mientras la contienda está teniendo lugar y que desconoce su final.

Corea del Norte recibió la ayuda de la China de Mao Tse Tung, llegado al poder el 1 de octubre de 1949, y de la Unión Soviética de Stalin; y por su parte la del Sur tuvo el apoyo de la ONU, esencialmente de los Estados Unidos del presidente Harry S. Truman y a partir del 29 de noviembre de 1952 de su sucesor Dwight D. Eisenhower, así como de otros varios países entre los que se contaban Francia y el Reino Unido. Como nos dice Pérez̧ (estr. 5), la contienda significó uno de los momentos más caliente de la llamada Guerra Fría y estuvo a punto de provocar la que hubiera sido la Tercera guerra mundial. Incluso el general americano Douglas MacArthur llegó a proponer el bombardeo atómico del norte de China, a lo que el Congreso americano se opuso (estr. 4). En cuanto a la llamada Guerra Fría recordemos que así se denominó el largo período de unos cuarenta años que media entre el final de la Segunda guerra mundial (1945) y el surgimiento en Rusia de la Perestroika (1985) y el fin del comunismo, período en que un buen número de potencias occidentales y la URSS estuvieron enseñándose los dientes y echándose un pulso por el dominio ideológico, económico y político del mundo.

${ }^{198}$ Sobre otras coplas de Pérez̧ que abordan el mismo tema vid. nota 160 supra. 
Veamos ya el texto.

1 En Purim cada judió ${ }^{199}$ fiestaba con gusto, ma el uśo se pedrió: no tiene lo justo ${ }^{200}$;

le viene deśgusto en viendo el dor cada día más peor, siempre complicado más que alocado.

2 Los que dićen querer paz pensan en la guerra, ellos encarecen más todo en la tierra ${ }^{201}$ y la Englitierra se apercibió que las armas que vendió a nuestros vićinos ${ }^{202}$ se haćen espinos...

3 El país del Tío $\operatorname{Sam}^{203}$ alarga la fiesta..., esta fiesta, bar minam, cavśará tempesta y miśmo la pesta si no meten fin; cale reglar de pišín, porque esta China va cavśar rubina.

4 Este pueblo de Budá ${ }^{204}$, miśmo que hambierto, es bastante huvardá en enĝentramiento... ${ }^{205}$; el manco despierto ${ }^{206}$ tiene un chiflic...

$\mathrm{Ni}$ la bomba atomic ni otra mortajá ${ }^{207}$ no lo descoraja.

5 No se entiende colay lo de la Corea ${ }^{208}$, ma el espanto que hay es que la pelea

${ }^{199}$ Alexandro Pérez̧ se plagia a sí mismo repitiendo el íncipit de su copla Las promesas de los gobernantes (Baecs núm. 230a); vid. RoMERo Entre dos cap. 13 núm. 132 (edición del texto en págs. 637-641), y Y hubo luz pág. 37 núm. 32 y la bibliografía allí anotada (edición del texto en págs. 265-268).

${ }^{200}$ Es decir, le falta el dinero necesario para celebrar la alegre fiesta como se debe.

${ }^{201}$ Es decir, esas amenazas de guerra hace que la crisis económica se acentúe.

${ }^{202}$ Se refiere a los países árabes del entorno de Israel.

${ }^{203}$ Alusión que todos conocemos a Estados Unidos.

${ }^{204}$ Acentúo así por mor de la rima.

${ }^{205}$ Alusión irónica a la fertilidad de los chinos.

${ }^{206}$ Es decir, el más tonto.

${ }^{207}$ Aquí con el sentido de 'mal muy grave'.

${ }^{208}$ Está aludiendo a la Guerra de Corea. 
mucho se menea para se anchar ${ }^{209}$,

lo que puede carear

una nube preta en nuestra planeta.

6 Sola una fuerza hay: el Todo Potente, para Él es muy colay salvar el Oriente y el Occidente de la sekaná

o de la casapaná

o las envanciones por matar miliones ${ }^{210}$.

7 Nos aḅracemos con Él todos los creyentes, sobre todo Israel y sus sufrientes, porque los vinientes $^{211}$ queren pan y paz. ¡Artic!, no se sufre más, la guerra yelada ${ }^{212}$ nos deǰa sin nada.

\section{ÍNDICE DE TÍTULOS DE LOS POEMAS EDITADOS}

La avaricia de los ricos de 1939: núm. 11

La avaricia de los ricos de 1940: núm. 13

Bejor Carmona, Yeḥeźquel Gaḅay y el armenio Duz Oglú: núm. 2

El bombardeo de Belgrado de 1862: núm. 3

Caos comunitario en la Constantinopla de 1922: núm. 8

El Dios de la salvación: núm. 7

Dios proteja a Abdul Hamid: núm. 6

El incendio de Sarajevo de 1879: núm. 5

La independencia de Israel: núm. 15

La invencible crisis de 1926: núm. 9

Los males de 1940: núm. 12

Los males de 1952: la Guerra Fría y la Guerra de Corea: núm. 19

${ }^{209} \mathrm{El}$ autor teme que esta guerra provoque un conflicto generalizado.

${ }^{210}$ Entiendo que está aludiendo a la bomba atómica, pero también puede ser una alusión al Holocausto.

${ }^{211}$ Entiendo que se refiere a las nuevas generaciones, pero también podría tratarse de un error tipográfico por vivientes.

${ }^{212}$ Es decir, la llamada Guerra Fría. 
Los males del invierno: núm. 18

La ocupación de Bosnia por los austriacos en 1878: núm. 4

Penurias en el Israel de 1949: núm. 16

Penurias en el Israel de 1952: núm. 17

La pérfida Albión de 1939: núm. 10

Rusdí Pachá y los judíos de Sarajevo: núm. 1

Tinieblas del Holocausto: núm. 14

\section{GLOSARIO}

abinu (hb. אבינו) 'nuestro padre'

abonanzado (cfr. esp. bonanzoso) 'próspero; bondadoso'

Abraham (hb. אברהם) 'Abraham'

acelados 'celadas, trampas'

adar (hb. אדר): sexto mes del calendario judío; tiene generalmente 29 días y su

comienzo oscila entre el 1 de febrero y el 12 de marzo; en los años bisiestos

se le añade un día amén de un segundo adar de 29 días

afeites 'adornos, aderezos, atavíos'

afilú (hb. אפילו) 'aunque'

afito 'ahitera, indigestión, empacho'

aflojarse 'rendirse; debilitarse'

Aganá: vid. nota 180

'a”h (hb. עלע, siglas de hb. עליו השלום 'alav hašalom) 'sobre él sea la paz'

ajustado: vid. notas 25 y 45

ajustamiento (cfr. fr. ajout) 'añadido, añadidura'

alayé, ilayé: vid. nota 65

albicias, alvicias 'albricias', vid. nota 67

albor: vid. nota 114

alguaya (esp. guaya) 'grito de lamento, queja', vid. nota 9

al had 'domingo'

alimpiar: vid. nota 150

almanot (hb. אלמנות) 'viudas'

alvicias: vid. albicias

ancharse 'ampliarse, extenderse, hacerse más amplio', vid. nota 209 
andoladas 'con el pelo ondulado'

apañar 'reunir'

apartar 'distinguir, hacer diferencias'

apartenir '(fr. appartenir) 'pertenecer'

apercantar 'asombrar, encantar'

aprobada: vid. nota 8

aquedada 'apaciguada, tranquilizada'

aquerenciar 'amar, querer'

arap (tc. Arap) 'árabe'

aréś: vid. nota 127

aribar: vid. nota 99

Ariel: vid. 'avonot

armadas (fr. sing. armée) 'ejércitos'

artic (tc. artık) ¡basta ya, ya está bien!

aškenaźí: vid. nota 69

atagantados 'desmoralizados, deprimidos'

avante (esp. ;avante!, it. avanti $;$, fr. avant $;$ ) ' ‘adelante!'

avenir (fr. avenir) 'futuro, porvenir'

'avonot golat Ariel: vid. nota 73

axeptar: vid. nota 111

'ayin hará' (hb. עיין הרע) 'mal de ojo'

ba 'avonot (hb. בעוונות) 'por desgracia' (lit. 'por los pecados')

bar minam (hb. בר מנן bar minán) 'Dios nos libre'

barraganes 'héroes'

batir 'temblor, estremecimiento'

be 'eźrat haEl: vid. nota 72

belá (tc. belâ) 'desgracia, calamidad'

bené tobim: vid. nota 92

benonim: vid. nota 46

bet hakenéset (hb. בת הכנסת) 'sinagoga'

bibiendas 'bebidas'

bilmem ne: vid. nota 183 
blocado (fr. bloqué) 'bloqueado'

bombardimá (tc. bombardıman) 'bombardeo'

borón (cfr. fr. bureau) 'caja fuerte'

boticas 'tiendas'

brío: vid. nota 196

brullón (fr. brouillon) 'borrador'

budĝé (fr. budget) 'presupuesto'

bultero: vid. nota 126

buqueto (fr. bouquet) 'ramillete'

caḅiné (fr. cabinet) 'retrete'

calé (tc. kale) 'fortaleza, castillo'

caler (esp.) 'haber de, tener que'

calmo (cfr. it. calmo adj. 'tranquilo') 'calma, tranquilidad'

canones (fr. sing. canon, it. sing. cannone) 'cañones'

canseriośo 'cansado, fatigoso'

canso 'cansado, fatigado, agotado'

capos (it. sing. capo) 'guías, jefes'

carear 'acarrear, provocar'

caśal: vid. nota 98

casapaná (tc. kasaphane) 'matadero'

cavané, pl. cavanés (tc. sing. kahvehane) 'local(es) para beber café'

cavé (tc. kahve) 'café'

caźic (tc. kazı 'palo, estaca; empalamiento') 'suplicio, tortura', vid. nota 133

c”c (hb. קהל קדוש cahal cadóš) 'santa sinagoga'

cerados 'encerrados'

čhampión (tc. şampiyon, fr. champion) 'campeón'

charši (tc. çarşı) 'mercado'

chiflic (tc. çiflik, çiftlik) 'granja'

chiźmés (tc. sing. çizme) 'botas altas'

choc yašá (tc. çok yaşa) 'larga vida'

clementinas (esp.) 'mandarinas'

colay (tc. kolay) 'fácil; fácilmente' 
comecinas 'comecomes, picazones'

compośar (fr. composer) 'componer'

contino: de — 'continuamente'

conyurarse (it. congiurare 'conjurar') 'conjurarse'

criś (fr. crise) 'crisis'

cualunque (it. qualunque) 'cualquiera'

cuantas 'muchas'

cuantunque (it. quantunque) 'aunque'

cuatriguado: ser — vid. nota 14

cuicirse 'cocerse'

cumular: vid. nota 105

dacios 'tributos, impuestos'

deficito: vid. nota 105

defús (hb. דפוס) 'imprenta'

demaśías 'excesos, grandes cantidades', vid. nota 24

deperiendo 'perdiendo'

derahim: dar —: vid. nota 175

descorajar (fr. décourager) 'desalentar, acobardar'

deślečhar: vid. nota 118

deśmaźalados (cfr. hb. מזל maźal 'suerte, fortuna') 'sin suerte, desgraciados, sin maźal'

diñitá (it. dignità) 'dignidad'

dober (it. dovere) 'deber'

dogramá (tc. doğrama) 'carpintería', vid. nota 190

dor (hb. דור) 'generación'

draḥme (tc. dirhem, ngr. $\delta \rho \alpha ́ \mu \mathrm{u})$ 'dracma'

efsat, evsat: vid. nota 65

El: vid. nota 70

embeźar 'aprender'

empecijo 'principio, comienzo'

empleo (esp. emplear 'gastar el dinero en una comprar') 'compra', vid. nota 87 
emportar (fr. importer) 'importar, resultar ventajoso'

empuǰs 'retortijones'

enfirmo (fr. infirme) 'enfermizo, achacoso'

engajamiento (fr. engagement) 'compromiso'

Englitierra 'Inglaterra'

englutir (esp.) 'tragar, engullir'

engrandeciendo: vid. nota 11

enmentar 'mencionar, mentar; recordar'

enpreśado 'apresado'

ensabanado 'zalamero, hipócrita, solapado'

entrepiśas (fr. sing. entreprise) 'empresas'

enturcado: vid. nota 34

envanciones (fr. sing. invention) 'inventos'

escapado 'liberado'

escapar 'liberar, salvar', 'terminar'

escarcedad 'avaricia, mezquindad'

escarsos (esp. sing. escaso) 'avaros'

esculcar (esp.) 'buscar con minucia y cuidado'

eškoliot (hb. אשכוליות eškoliyot) 'pomelos'

espandiduras 'espacios, territorios'

esprito (fr. esprit, it. spirito) 'espíritu'

estancia: vid. nota 85

estrazos 'daños, estragos'

evenimientos (fr. sing. événement) 'sucesos, acontecimientos'

eviva (it. evvivai) 'iviva!'

evsat: vid. efsat

ex́empio (it. esempio, fr. exemple) 'ejemplo'

felaj, pl. felahimim (tc. sing. fellâh) 'árabe(s)'

felec (tc. felek 'firmamento', 'destino, hado') 'mundo, época; actualidad'

feraj: vid. nota 130

fesat: vid. nota 64

fey 'fe' 
fieros 'hierros'

fonsado 'ejército'

forestos 'forasteros', vid. nota 91

fortunośa 'tormentosa'

fragua 'construcción'

fraguar 'construir'

fronte (fr. front) 'frente, primera línea de combate'

fundido 'hundido'

gailet (tc. gaile) 'ansiedad, preocupación'

gajo: vid. nota 131

galut (hb. גלות) 'diáspora'

garato 'alosa en salmuera, pescado salado'

garnidas (fr. sing. garnie) 'guarnecidas, provistas'

gaźi (tc. gazi) 'vencedor, campeón'

genayo (it. gennaio) 'enero'

gep, pl. gepes (tc. sing. cep) 'bolsillo(s)'; meter mano al — 'dar dinero, rascarse el bolsillo', vid. nota 154

golat: vid. 'avonot

goyim (hb. גוים) 'gentiles, no judíos'

grandor (fr. grandeur) 'grandeza'

gritaronas 'gritonas, protestonas'

grušes (tc. sing. guruş, kuruş) 'piastras'

gualadronar 'premiar, galardonar'

guay (esp.) ¡ay!

guayas (esp.) 'quejas, lamentos'

guebir, pl. guebirim (hb. גביר, pl. גבירים) 'rico(s); persona(s) importante(s)', 'notable(s) de la comunidad, dirigente(s)', vid. nota 143

haberim (hb. חברים) 'socios; amigos'

hacinuras 'enfermedades'

haEl: vid. be'eźrat 
hair : vid. nota 157

hajamim (hb. חכמים) 'sabios, rabinos'

hakenéset: vid. bet

hambierto 'hambriento'

hará': vid. 'ayin

harbado 'golpeado'

harbar 'golpear'

haroba 'algarroba', vid. nota 117

haruźim (hb. חרוזים) 'rimas'

hašmonim: vid. nota 173

hatir: vid. nota 177

hayom (hb. היום) 'hoy'

hecdešot (hb. הקדשות) 'donaciones, bienes entregados a la comunidad', vid. nota 82

hechicos 'negocitos'

hešboón (hb. חשבון) 'cuenta'

hִešván (hb. חשוון): segundo mes del año judío; tiene veintinueve o treinta días y su comienzo oscila entre el 6 de octubre y el 4 de noviembre

hey 'allí, ahî'

homaǵe (fr. hommage) 'homenaje'

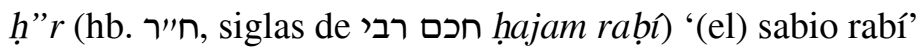

huvardá (tc. hovarda) 'generoso, liberal'

ilayé: vid. alayé

importables 'importantes'

imprimería (fr. imprimerie) 'imprenta', vid. nota 190

inserar (fr. insérer) 'insertar'

iyar (hb. אייר): octavo mes del calendario judío, su comienzo oscila entre el 12 de abril y el 11 de mayo

jemanfutistas (fr. sing. je-m'en-foutiste) 'indiferentes, viva la virgen, pasotas' jerif (tc. şerif) 'jerife'

jones: vid. nota 178 
kabod (hb. כבוד) 'honor, honra'

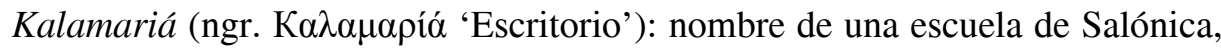
probablemente situada en el barrio de ese nombre

kolel (hb. כולל) ‘consejo comunal laico'; ‘comunidad';'dirigentes comunitarios'

labor (cfr. it. lavoro) 'trabajo'

laborar (cfr. it. lavorare) 'trabajar'

laźrar 'trabajar, esforzarse'

liras (it. sing. lira, tc. sing. lira ): unidad de moneda turca

londra (it. londra) 'libra esterlina (moneda de oro)'

lusos (it. sing. lusso) 'lujos'

$m a(($ it. $m a$, tc. $a m a)$ 'pero'

ma'asé, pl. ma 'asiyot (hb. מעשה, pl. מעשיות) 'relato(s), narración(es)'

malgrado (it. malgrado, fr. malgré) 'a pesar de'; —— todo (calco del fr. malgré tout) 'a pesar de que, con todo'

malhor (fr. malheur) 'desgracia, infortunio'

mamparos 'amparos, refugios'

maná 'mamá, mami'

mancanza (cfr. it. mancare, fr. manquer) 'error; falta, detrimento'

mancar (it. mancare, fr. manquer) 'faltar'; _ de 'estar falto de'

manco (it. manco) 'menos', vid. nota 206

manobrar (fr. manoeuvrer) 'maniobrar'

marmullas 'protestonas, refunfuñonas'

maŝá (hb. מצה): pan ázimo de uso obligatorio durante la fiesta de Pésaḥ

me amarim, meamarim: vid. notas 142 y 168

meanés (tc. sing. meyhane) 'tabernas'

Mejlis: vid. nota 83

meldando 'rezando'

membración (cfr. esp. membrar) 'recuerdo, memoria'

memuné, pl. memunim (hb. ממונה, pl. ממונים) 'miembro(s) del consejo comunal, dirigente(s) de la comunidad' 
menaḥem (hb. מנחם): nombre que también recibe el mes de $a b$ (hb. אב), undécimo del calendario judío; tiene 30 días y su comienzo oscila entre el 9 de julio y el siete de agosto, vid. nota 36 mestieres (fr. sing. métier) 'oficios' meźo (it. mèzzo) 'medio' mirácolos (it. sing. miràcolo) 'milagros' miśmo (cfr. fr. même) 'también, incluso' mortaja: vid. nota 207 musar (hb. מוסר) 'moral' neemán (hb. נאמן) 'fidedigno' nemŝí, pl. nemŝî́s (tc. sing. Nemse, Nemçe) 'austriaco(s)'

niflaot: vid. 'osé nisim (hb. נסים) 'milagros' notencias 'noticias' nR”u (arm. נטריה רחמנה ופרקיה natreh Rahamaná ufarqueh)

'Dios le guarde y le conserve'

'od (hb. עוד) 'aún, todavía' 'osé niflaot: vid. nota 62 osmanos 'otomanos' otobús (fr. autobus) 'autobús'

paćiguośo 'paciente, apaciaguador' Padišaḥ, Padišá (tc. padişah) 'sultán, Padisá' palomba 'paloma' pará, pl. parás (tc. sing. para) 'moneda(s), dinero' Paradiśo (it. paradiso) 'Paraíso' parfecto (cfr. fr. parfait) 'perfecto' partal: tomar —: vid. nota 182 parvenir (fr. parvenir) 'lograr, conseguir', 'llegar' pendar (ngr. $\pi \varepsilon v \tau \alpha \dot{\rho} \rho \alpha)$ 'moneda de poco valor' Pésaḥ (hb. פסח) 'Pascua', una de las tres festividades mayores, de peregrinación a Jerusalén en tiempos bíblicos, en que se conmemora el éxodo de Israel del 
Egipto faraónico y la liberación del cautiverio, vid. nota 100 pesta 'peste, cólera' pilaf (tc. pilâv) 'arroz' pimienta: vid. nota 146 piripañas: vid. nota 158 pišin (tc. peşin, pişin): de — 'inmediatamente, al instante, con urgencia' piźmonim (hb. פזמונים) 'poemas litúrgicos'

plomada: vid. nota 39 podestán (cfr. it. podestà 'potestad, poder') 'que gobierna, que manda' podestar (cfr. it. podestà 'potestad, poder') 'dominar, mandar, gobernar' portanto (fr. pourtant) 'sin embargo' portocales (tc. sing. portakal) 'naranjas' pośar (fr. poser, it. posare) 'poner, depositar', 'caer' presto (it. presto) 'pronto, enseguida': más — 'antes' preta 'negra', vid. nota 93 profito (it. profitto, fr. profit) 'provecho' program (fr. programme) 'programa' prontos (it. sing. pronto) 'preparados, dispuestos' pujando 'aumentando' puntada 'pulmonía, pleuresía'

Purim (hb. פורים): festividad menor en la que se conmemora la salvación milagrosa del pueblo judío en la Persia del rey Asuero, según se relata en el libro bíblico de Ester; su celebración ofrece rasgos de carácter carnavalesco purimlic (hb. Purim + tc. -lık) 'aguinaldo de Purim'

queŝabot (hb. קצבות) 'tasas, impuestos' questiones (fr. sing. question) 'cuestiones' quief (tc. keyif) 'buen humor, alegría, diversión', 'gusto, deseo, gana' quiefur (tc. küfür 'blasfemia'): haćer — 'encolerizar, hacer blasfemar' quienar (tc. kenar 'rincón'): dejar en un —— 'dejar de lado, olvidarse de' quiesat (tc. kesat) 'crisis económica; carestía' quiinas: vid. nota 151 quina: vid. nota 137 
rab (רb. רב) 'rabino, rabí, maestro'

radiośo (it. radioso) 'radiante, resplandeciente'

rahamán (hb. רחמן) 'misericordioso'

rahamanut (hb. רחמנות) 'misericordia'

Rambam (hb. רמבם, acrónimo de rabí Mošé ben Maimón) 'Maimónides'

reclama 'reclamo'

regalados 'muy queridos, adorados, mimados', vid. nota 172

regmido 'redimido'

rehmidor 'redentor'

reḥmir 'liberar, redimir'; reḥmirse 'ser liberado, redimido'

rematado: vid. nota 17

rengraciar (it. ringraziare) 'agradecer a, dar gracias a'

reśbalatinas 'resbalones, caídas'

rescaldada 'calor, rescoldo'

respecto (cfr. fr. respect) 'respeto, consideración'

resurzas (fr. sing. ressource) 'recursos, medios económicos'

revenir (fr. revenir) 'volver, regresar'

rob (hb. רוב): el — 'en su mayor parte'

rojarse 'arrojarse'

rubina (it. rovina) 'ruina'

rusat: vid. nota 63

ruyir 'lamentarse, rugir de cólera o de desesperación'

šaḅat (hb. שבת) 'sábado'

safañones 'sabañones'

šaliah (hb. שליח) 'enviado, mensajero'

šapchí (tc. şap + -cl, -çl) 'aprovisionador de alumbre'

Saray 'Sarajevo'

šébaḥ laEl: vid. nota 71

secaturas (it. sing. seccatura) 'preocupaciones graves', 'molestias, pejigueras, engorros'

sedacá (hb. צדקה) 'limosna, donación'

sefarim (hb. ספרים) 'rollos de la Ley para uso sinagogal' 
séfer Torá (hb. ספר תורה) 'rollo del Pentateuco para uso sinagogal'

séjel (hb. סכל) 'inteligencia, conocimiento', vid. nota 66

sekaná (hb. סכנה) 'peligro'

Šemá: vid. nota 170

sengeres (tc. sing. sencer) 'fortalezas, barricadas'

senso (it. senso) 'sentido'

sidear: vid. nota 154

simán (hb. סימן) 'señal, signo', 'acróstico'

siván (hb. סיון): noveno mes del calendario judío; tiene 30 días y su comienzo oscila entre el 11 de mayo y el 9 de junio

Siyón (hb. ציון) 'Sión'

šóhad (hb. שוחד) 'Soborno, cohecho'

someno: vid. nota 113

šosones (tc. sing. şoson, fr. sing. chausson) 'chanclos'

sudecer 'suceder'

Sukot (hb. סוכות): fiesta de las Cabañuelas; una de las tres festividades mayores, de peregrinación en los tiempos bíblicos; comienza el 15 de tišrí y dura una semana, en la cual es preceptivo residir o sentarse a comer en cabañas construidas al efecto en jardines o terrazas

survellar (fr. surveiller) 'vigilar'

tam (hb. תם) 'se acabó, acabado'

taxaciones 'impuestos'

tebet (hb. טבת): cuarto mes del calendario judío; tiene 29 días y su comienzo oscila entre el 4 de diciembre y el 2 de enero

tefilot (hb. תפילות) 'oraciones'

tiros 'cañones'; 'cañonazos'

tišrí (hb. תשרי): primer mes del calendario judío, su comienzo oscila entre el 6 de septiembre y el 5 de octubre

toaf (tc. tuhaf, tohaf) 'cómico, divertido'; 'extraño, raro, curioso'

tobim: vid. bené

todo: del — vid. nota 169

trabarse: vid. nota 81

tram (fr. tram) 'tranvía' 
trespasar 'pasar de la raya' (en sentido negativo)

trublar (cfr. fr. troubler) 'turbar, alterar'

unflados 'hinchados'

untado 'ungido', vid. también nota 164

uśo 'costumbre'

valible 'válido'

vatán (tc. vatan) 'patria, país'

veadar (hb. ואדר lit. 'y adar'): mes que en los años bisiestos del calendario hebreo se añade tras el mes de adar

yolando 'muriendo'

yoltado 'convertido (a otra religión)'

$y$ tb. 'también'

yašá: vid. choc

y“E”a (hb. יע״א, abrev. de יכוננה עליון אמן yejonenah 'Elyón, amén) 'el Alto

(Dios) la cimiente, amén'

yehudim (hb. יהודים) 'judíos'

yešibot (hb. ישבות) 'escuelas rabínicas'

yetomim (hb. יתומים) 'huérfanos'

yišme 'elim (hb. ישמעאלים) 'musulmanes, ismaelitas'

Yisrael (hb. ישראל) 'Israel; el pueblo judío'

yulés (tc. sing. gülle) 'proyectiles'

źemán (hb. זמן) 'tiempo, época', vid. nota 87

Recibido: 15/12/2010

Aceptado: 15/05/2011 